\title{
Grundtvigs vej til Saxo
}

\author{
Flemming Lundgreen-Nielsen
}

Grundtvigs forhold til Saxo fra 1787 til foråret 1815, hvor han besluttede at nyoversætte Gesta Danorum, opridses gennem dateringer, bogtitler og andre pålidelige hjælpemidler og illustreres gennem autentiske citater ledsaget af forklarende karakteristik. Saxos aktive rolle i Grundtvigs liv var reelt udspillet i 1823, da det 3. og sidste bind af oversættelsen sendtes af sted til subskribenterne i Danmark og Norge. Den sprogligt-stilistiske side af Grundtvigs danske Saxo-tekst 18181822 og de utrykte papirer om den er pænt dækket i forskningen. Dette suppleres her med en behandling af de faghistoriske og nutidige vurderinger, Grundtvig anlagde på Saxo i løbet af sit lange liv, trykte så vel som utrykte. ${ }^{1}$

\section{Forudsætningerne}

Grundtvig blev i 1783 det sidstfødte barn af fem (overlevende), med en fader på 49 og en moder på 35 år. Frederik, som hans kaldenavn lød, var ifølge sin viljestærke moder født til at udgøre det fjerde blad på et firkløver af teologiuddannede sønner og skulle holdes til bogen (jf. dedikationsdigtet til hende i digtsamlingen Kvadlinger, 1815). "Under Graad og Hjertevee" (US III, 67) lærte han som fire-femårig pog bogstaverne af hende, men snart tilegnede han sig "som en Leeg sin Bog”. Om aftenen lod moderen ham læse "Reent og klart med høien Røst" om gamle dage (historie), og faderen kom så ud "fra sin Præstecelle" og gav realkommentarer til, hvad moder og søn ikke forstod. Den lille Frederik var efter egne

${ }^{1}$ Bidraget er holdt som foredrag på Københavns Universitet for forskerstuderende i historie 21. maj 2014 og senere udvidet som et sidestykke til Gustav Albecks foredrag "Grundtvigs Vej til de norrøne Skrifter" i Grundtvig-Studier 1953 (103-111). 
udsagn ikke begavet for kropslige udfoldelser og klarede sig dårligt over for sin kun ét år ældre søster. At danse, synge og musicere lærte han aldrig. At spille kort, vende blade $\mathrm{i}$ en bog og skrive med en pen var de håndværk, han kunne. Tidligt blev han således ifølge erindringsdigtet "Udby Have" (i samlingen Saga. Nytaarsgave for 1812, udg. 23. december 1811) en grovæder med "Tærskersult og Tærskermave" (US II, 139).

Alligevel er Grundtvigs forhold til Saxo langtfra en sag om kærlighed ved første blik. I årene før studietiden i København 1800-1803 synes han af tilfældige årsager ikke at have læst Saxo.

Faderens bibliotek i Udby præstegård findes der en fortegnelse over dateret 13. oktober 1789 (Fasc. 544), men det var ikke imponerende, fordi denne i sine fleste leveår havde økonomiske problemer. ${ }^{2}$ I Grundtvigs egen redegørelse for sin barndoms og første skoletids læsning i "Udby Have" (på i alt 694 verslinjer) er Saxos navn slet ikke nævnt. Han forekom dog $\mathrm{i}$ hvert fald i henvisninger hos de andre danske historikere, som Grundtvig slugte i hjemmet (C.C. Lyschander, Jonas Ramus, Ludvig Holberg og P.F. Suhm).

Skolelærer i Grundtvigs Udby-barndom var fra 1788 Bertel Faurskov (1729-1806), en glødende franskorienteret revolutionær på 59 år. Grundtvig lærte latin af ham 1789-1792, mest dog som en udenadslektie, fordi den lærde mand ikke formåede at afpasse sin undervisning til elevernes fatteevne.

Latin-undervisningen fortsatte, da Grundtvig tilbragte årene 1792-1798 hos pastor Laurits Feld i Thyregod (35 km NV for Vejle) - dog med en halvanden måneds tid hjemme hver sommer. Feld havde som huslærer $\mathrm{i}$ Udby undervist hans to mellemste brødre, og som ugift sognepræst drev han en lille privat kostskole midt på den jyske hede sammen med en ligeledes ugift søster. En fortegnelse over Felds private bogsamling omfatter i alt 116 titler, fortrinsvis teologi, skolebøger og ordbøger (jf. GrundtvigStudier 1982, 72, note 2), men Saxo er ikke med på den, ${ }^{3}$ og Grundtvig har ikke nævnt Saxo i forbindelse med sine seks skoleår i Thyregod. Det

2 Det vides dog, at Johan Grundtvig i 1762 anskaffede sig Snorres Heimskringla i Peder Claussøn Friis' danske oversættelse, formentlig den forbedrede og forøgede 2. udgave i kvart fra 1757 (jf. Rønning 1904, 44).

3 Et eksemplar af bogfortegnelsen findes på Grundtvig-biblioteket i Vartov. Feld ejede dog Finnur Jónssons Historia Ecclesiastica Islandia, I-IV, 1772-1778 - det værk fra faderens bibliotek, Grundtvig som nyudklækket arbejdsløs cand.theol. i 
latin, Feld havde lært ham, erfarede han senere var solidt nok. Grundtvigs latin-uddannelse blev afrundet på Aarhus Katedralskole fra oktober 1798 til september 1800. Skolebiblioteket ejede Saxo på latin i 1576-udgaven fra Frankfurt a. M. og desuden 1610-optrykket af Anders Sørensen Vedels 1575-oversættelse til dansk. Om Grundtvig interesserede sig for dem i denne periode, vides ikke. Derimod lånte han nogle af P.F. Suhms skrifter, bl.a. bindet $O m$ Odin, 1771 (der jo i hvert fald i fodnoter og få latinske citater henviser til Saxo). Ved adgangsprøven (examen artium) til Københavns Universitet 27. september 1800 fik Grundtvig laud.p.c., dvs. topkarakter med udmærkelse (pre ceteris) i latin. Ved den filologiske prøve 12. oktober 1801 måtte han i sprogene latin, græsk og hebraisk nøjes med tre gange haud illaud, dvs. anden karakter (Bugge 1965, 57).

Efter eget udsagn var Grundtvig som universitetsstuderende ikke videre interesseret i sit fag, gik ikke i kirke og læste som sine ældre brødre i høj grad teologi efter moderens ønske og ordre. En noget for selvsikker redegørelse for attestatsens afslutning i oktober 1803, skrevet et halvt år senere, er præget af Grundtvigs stolthed over de fif, han tillod sig over for de velvillige eksaminerende myndighedspersoner (Albeck 1979, 35-42). Han endte med at få laudabilis uden at have slidt meget på universitetets auditoriebænke.

\section{Supplerende kilder}

Grundtvigs egne oplysninger om sin uddannelse kan suppleres ad andre veje.

En oversigt over indholdet af den voksne og modne Grundtvigs privatbibliotek er udfærdiget af den ældste søn Johan (f. 1822) i juli-august 1839 og opbevaret i Grundtvig-arkivet (Fasc. 520). Den blev fortsat af sønnen Svend (f. 1824) op mod 1847 til i alt 4.030 numre. Det bibliotek, Grundtvig efterlod ved sin død 2. september 1872, androg ifølge det trykte kata$\log$ til den offentlige auktion 29. september 18738.979 fremmede tekster (hvortil kom et uidentificeret bundt skrifter), og tryk af Grundtvigs egne tekster i forskellige udgaver beløb sig til 961 numre. Inden auktionen må

højsommeren 1804 i Udby begyndte at lære sig selv oldislandsk efter (ved hjælp af islandske digte med latinske paralleltekster, især i bind II, 1774, 398 ff.). 
Grundtvigs børn, navnlig den boglige Svend, have taget fra, hvad de ønskede at eje. Disse kilder opgiver ikke anskaffelsestidspunkter.

Andre aktiviteter, Grundtvig deltog i, er usikrere oplyst. Han havde kortvarigt adgang til læseforeninger (private bogklubber, som fortrinsvis indkøbte og rundsendte nyudkomne bøger og ditto tidsskrifter). Pastor Feld var medlem af et læseselskab i Vejle og lod sine elever læse, hvad der indløb derfra; herunder husker Grundtvig skrifter af Rahbek, P.A. Heiberg, Malthe Conrad Bruun og T.C. Bruun. For at følge med stiftede Grundtvig på Egeløkke selv et Langelands Læseselskab 8. november 1805, som han var formand for til 14. januar 1808. Foruden Constance Leth talte det kun en halv snes præster på øen. En forargelse i 1807 over indkøbet af bind I af en ny dansk Boccaccio-oversættelse (ved Odin Wolff 1805) affødte en debat om tekstens smudsigheder, som endte med fire præsters udmeldelse af foretagendet. Grundtvigs varige gevinst blev Friedrich Leopold Stolbergs tyske Ossian-oversættelse i tre bind 1806, som de resterende medlemmer forærede ham til tak for hans formandskab. Endelig var han som alumne på Valkendorf medlem af et Societas Litteraria på Regensen fra 3. juli 1808 til 1. januar 1810 (Lundgreen-Nielsen 1982, 63-73), der dog næppe betød noget for hans udvikling.

Da Grundtvig begyndte at studere teologi i København i 1800, var han så dårligt orienteret, at han for tidsfordriv lånte underholdende bøger på et kommercielt lejebibliotek. Først i 1801 blev han opmærksom på, at han som student og uden at betale noget var berettiget til at låne bøger på Universitetsbiblioteket. Dette har dog først bevaret låneprotokoller så sent, at det blotte efternavn Grundtvig også kan være sønnerne Johan eller Svend (Toldberg 1946, 38). Det Kongelige Bibliotek åbnede fra 1793 adgang for offentligheden, men den ældste bevarede låneprotokol er fra 1803. I senere bind optræder Grundtvig en del gange (f.eks. med lån af udenlandske historiske værker).

Nogle tidlige boghandlerregninger er tilfældigt overleveret, men omfatter så få titler, at misforholdet til, hvad han ejer ved sin død i 1872, er stort. På sine tre akademiske Englandsrejser 1829-1831 købte Grundtvig godt ind, men nogle af disse bøger var efter aftale med Molbech erhvervet på vegne af Det Kongelige Bibliotek (lister fra navnlig 1829 kan ses i Albeck 1979). I alt 46 enheder med regninger rækkende fra 1808 til 1858 er bevaret i Grundtvig-arkivet (Fasc. 521), en god del dog uden oplysning om de købte bøgers titler. 
Det er muligt, at Grundtvig i forlængelse af mundtlige drøftelser med studiekammerater 1800-1803 og Valkendorf-alumner 1808-1811 har lånt læsestof privat (hvad der kan have gentaget sig under hans tre sommerlige studierejser til England, især ved hans ophold på Trinity College i Cambridge det sidste år, 1831). I Egeløkke-tiden er lån eller læsning på privatbiblioteket på Tranekær Slot en mulighed, der vist ikke er undersøgt nøje. ${ }^{4}$

Grundtvigs private korrespondance er for det meste en temmelig tynd affære. De sagligt mest interessante breve om ikke-teologiske spørgsmål findes i brevvekslingen med B.S. Ingemann 1821-1859 (Grundtvig 1882).

Endelig er der Grundtvig-arkivet med hans håndskrifter. Han etablerede det i 1797 eller 1798 - det sidste årstal står på autodateret tekst, som han således gemte på fra sit 14. år. Det omfatter i alt 535 pakker (fascikler) med manuskripter af vekslende omfang. Som fuldvoksen flyttede han omkring 25 gange (på kalenderens officielle flyttedage) rundt i København og allernærmeste omegn (Christianshavn, Frederiksberg, Hellerup), og der må hele hans arkiv have ligget fremme på gaden til afhentning ved professionelle flyttefolk, som så læssede det af på gaden ved hans nye bolig. Trods dette har samlingen overlevet intakt. Efter hans tredje og sidste hustrus død i 1890 deponerede familien den i Rigsarkivet, og i 1941 overførtes den til Det Kongelige Bibliotek (og var under besættelsen fra 1943 sammen med hele håndskriftssamlingen evakueret til sikrere steder end Slotsholmen). I årene 1957-1964 udarbejdede en gruppe på 10 Grundtvig-forskere en duplikeret Registrant over N.F.S. Grundtvigs papirer i 30 bind på i alt 7.139 sider i A4-format (hvoraf de to sidste var registerbind til de 28 foregående binds udfyldte skemasider). Projektet blev realiseret i et samarbejde mellem Det Danske Sprog- og Litteraturselskab og Grundtvig-Selskabet af 8. September 1947. Her kan det navnlig hurtigt kontrolleres, hvilke forfattere og andre personer Grundtvig ikke har kendt eller omtalt. Det er således en udvidelse af universalregistret i Steen Johansens Bibliografi over N.F.S. Grundtvigs skrifter (IV, 1954). I digitaliseringen af Udvalgte Skrifter I-X (på netadressen www.ADL.dk, artiklen om Grundtvig) kan man desuden søge på samtlige person- og stednavne i dette formidable tekstudvalg og også på enkeltord. Endelig er den kom-

${ }^{4}$ Grevinde Charlotte Ahlefeldt-Laurvig, veninde med Constance Leth, var Schiller-begejstret og lod Grundtvig dels benytte, dels ordne sit tysk-orienterede privatbibliotek (Scharling 1947, 23 med note 53-54). 
plette digitalisering af alle de skrifter, Grundtvig fik trykt i levende live, sat i gang fra 2010 af Grundtvig Centeret, Aarhus Universitet, med indledninger, tekstkritik og kommentarer samt faksimiler af førstetryk. Her kan der ligeledes søges på enkeltord. Netadressen er www.Grundtvigsverker.dk, post- og arbejdspladsadressen er Vartov, København.

Yderligere ligger en del manuskripter i særsamlinger som Ny Kongelig Samling (NkS) og Additamenta på Det Kongelige Bibliotek, skønsmæssigt omkring 2.400 manussider. Og mere endnu kan gemme sig på andre biblioteker og arkivinstitutioner eller være i privat eje.

Medregnet Grundtvigs bevarede breve kommer det til nu verificerede håndskriftsmateriale antagelig op på ca. 92.000 manuskriptsider. Hovedparten er utrykte, og intet enkelt menneske har førstehåndskendskab til det hele.

\section{Saxo - en usikker start}

Da Grundtvig i foråret 1801 havde læst teologi i næsten et år, traf han lige efter slaget på Reden 2. april den jævnaldrende bornholmer P.N. Skougaard (1783-1838) i en til lejligheden oprettet halvmilitær akademikerenhed kaldet Kronprinsens Livcorps. Skougaard blev på et både personligt og fagligt niveau den eneste jævnaldrende studiekammerat, Grundtvig kunne dele interesser med og lære noget af. Skønt egentlig matematiker imponerede Skougaard ham ved sin indsigt i historiske og filologiske områder og ved sin selvsikre uafhængighedsfølelse over for omverdenen. Ifølge fortalen til Nordens Mytologi 1808 ledte Skougaard Grundtvig på vej til "de vise Oldinge: Snorro og Saxo" (US I, 251).

Som nyuddannet cand.theol. på 20 år måtte Grundtvig i 1803 se i øjnene, at han ikke foreløbig ville få et kald i statskirken, og hans lyst gik også mere i retning af at blive historiker eller fri forfatter (eller begge dele ligesom Suhm). Efter råd fra Skougaard lærer Grundtvig på ni højsommeruger i Udby 1804 frem til fødselsdagen 8. september sig selv at læse oldislandsk. Det var et vigtigt gennembrud for ham, der - trods mangelen af en ordbog - satte ham i stand til at læse fremstillinger, der udelukkende var på islandsk. Beherskelsen af norrønt sprog gav hans interesse for nordisk oldhistorie et sikrere fundament. 
Selv om den purunge Grundtvig nok var bedre til latin end til islandsk, begynder hans Saxo-bekendtskab spagfærdigt og tilfældigt; Saxos retorisk-lærde omskrivninger er nok forekommet ham mere afstandsskabende end indtrængende. I ca. 1805 udfærdigede Grundtvig dog nogle utrykte og udaterede danske oversættelser af Saxos behandlinger af nordiske guder (Fasc. 267.1), med forlæg i den latinske 3. udgave fra Frankfurt a. M. i 1576. Det gælder kong Hadings ridetur over havet med Odin og hans hest og Hadings rejse til underverdenen (Liber I), trekantshistorien om Hother-Balder-Nanna, Odins hævn over Balders død, Odins Rusland-togt (Liber III) og Stærkodder (Liber VI). To af disse forsøg kan være valgt ud fra nyere gendigtninger, Johs. Ewalds syngespil Balders Død, 1775, og C. Prams epos Sterkodder, 1785. Grundtvigs prøveoversættelser er ikke i den tilstræbt folkelige borgestuestil, han lancerer i $1815 .{ }^{5}$

Grundtvigs privatbibliotek er registreret første gang 20. december 1805 af ham selv på Egeløkke (Fasc. 501.1); medregnet et lille, lidt senere tillæg tæller det 106 numre. Han ejer nu selv Vedels Saxo-oversættelse fra 1575 med den "søde" stil, mønstret for pastichesproget i Oehlenschlägers Vaulundurs Saga i dennes Poetiske Skrifter, II, 1805.

I sine væsentlige ungdomsafhandlinger trykt i K.L. Rahbeks månedsskrift Ny Minerva 1806-1807 hentyder Grundtvig kun hastigt til Saxo to gange, begge i artiklen om J. J. Dampes Signe (1807, 249 og 253). ${ }^{6}$ Nordens Mytologi udgivet 5. december 1808 (227 sider) indeholder Saxos navn 12 gange, ligeledes mest i forbigående (hvoraf de syv endda blot er kritiske fodnoter). ${ }^{7}$

Indbydelse til Gamle Nordens Venner, Grundtvigs subskriptionsplan fra december 1808, der bebuder et livslangt projekt med en gendigtning af al dansk oldhistorie (i skiftevis versificerede samtaler og berettende prosa), indbefatter en kommende brug af Saxo (US I, 378). Nordens Mytologi 1808 ser Grundtvig nu som en prosafremstilling, der opridser den religionshi-

5 Lundgreen-Nielsen 1980, 160 samt notetekst 13 på 422. Helge Toldberg antager i Reg. 1957 med urette, at noget af dette indgår i bind 1 af Grundtvigs Saxooversættelse i 1818.

${ }^{6}$ Hertil kommer dog betegnelsen "Saxos og Snorros de herlige Sønner" om historikere eller historiske digtere i "Om Videnskabelighed og dens Fremme, især med Hensyn paa Fædrelandet” i 1807 (US I, 179).

7 US I, 251, 254, 353, 357, 363 samt fodnoter på 265, 266, 269, 282, 291, 318, 355. 
storiske baggrund for alt, hvad der i sagnperioden foregår i det rent menneskelige niveau. Men foretagendet afbrydes og standses af Grundtvigs religiøse julekrise 1810 med følger langt ind i 1811. De talrige heroiske episoder, som han havde lovet skulle fylde rummet mellem de hedenske vølsunger på folkevandringstiden (emnet for Optrin af Norners og Asers Kamp, 1811) og den døende hedenskab i Norden hos Gorm den Gamle, Harald Blåtand, Svend Tveskæg og Palnatoke (emnet for Optrin af Kampelivets Undergang i Nord, 1809), tillod hans nyvundne religiøse overbevisning ham ikke længere at bruge tid og energi på at gendigte. Roar og Helge, Rolf Krage, Hamlet, Hervor med sværdet Tirfing, Signe, Sigrid og Stærkodder og meget andet måtte vige for den sjællandsk-danske kirkehistorie i Roskilde-Riim og for kristelig-moralske verdenshistoriske krøniker med vægt på Bibelens vurderinger. Meget af det udelukkede stof kunne Grundtvig ellers have opsøgt i Saxos første otte bøger om hedentroen i Norden.

I sit undervisningsmanuskript til historieklasser på Schouboes Institut 1808-1809 har Grundtvig i en historiografisk indledning citeret udsagnet fra "vor gamle Historieskriver Saxo Grammaticus" om, at oldtidens dansk-norske helte med runer indskrev fædrenes store bedrifter i klipper og sten, fordi de endnu ikke kunne latin eller kendte til bøger (Bugge 1968, I, 170 samt 287; Saxos Præfatio 1.3).

Saxo og Snorre, en sober mandjævning i 1809

"Lidet om Saxo og Snorro" (Fasc. 240, autodateret 1809) er offentliggjort i indeværende årgang af Grundtvig-Studier (37-53). Det er Grundtvigs første sammenlignende afhandling om Saxo og Snorre, endda bevaret i letlæselig renskrift (med gotiske bogstaver). Anledningen kan have været en trykt pjece (på 64 sider) med titlen Dr. G.L. Baden til Hr. Geheimekonferentseraad F. v. Moltke om vor danske Histories Fader Saxo Grammaticus og Trangen til en ny Udgave af ham, udgivet i Odense i august 1809. ${ }^{8}$

\footnotetext{
8 Baden nedgjorde dèr i en meget lang fodnote (82 linjer i petit) Grundtvigs Nordens Mytologi 1808 som et produkt af en tøjlesløs indbildningskraft (Baden 1809, 61-64, fastholdt ultrakort Baden 1815, 13-14).
} 
Grundtvig indleder sin tekst med udsagnet, at videnskaben ikke længere anser latinkundskab alene for et lærdomstegn, men snarere kræver oplysning "forbundet med kritisk Forskning og Granskning”. Det har medført hård og uretfærdig bedømmelse af Saxo fra en nutid, der vil have pålidelig dokumentation af alt, helst ved øjenvidner, og specielt lægger afstand til overtro som blot og bar løgn. Desuden er Saxo kommet i en forskningshistorisk klemme ved genopdagelsen især i det 18. århundrede af en overmægtig medbejler som Snorre Sturluson.

Grundtvig hentyder hermed til tre historiske teorier eller hypoteser, som Ludvig Holberg havde overskuet i sin latinske afhandling Solutio problematis de hypothesibus historia Danice fra 1731 (optrykt med dansk oversættelse i Kragelund 1974, I, 286-323, II, 123-133). Den almindeligste tese, af Holberg kaldt Hypothesis vulgaris, er, at det danske riges historie begynder med Saxos kongerække fra Dan til Knud VI. Den overtages af Saxos langt senere eftermænd, hamburgeren Albert Krantz (død 1517) med Chronica regnorum Aquilonarium, Daniæ, Suetix, Norvagix (posthumt fra Strasburg 1546) og i Danmark Arild Huitfeldt (10 bind omkring 1600, optr. i to folio-bind 1650-1652), den utrykte Hans Svaning og Johannes Meursius (1630). ${ }^{\text {? }}$

Den gotlandske eller gullandske hypotese ved teologen og historikeren Niels Pedersen eller Nicolaus Petrejus (ca. 1522-1579), trykt posthumt 1695, men benyttet i manuskript allerede af C.C. Lyschander i Danske Kongers Slectebog, 1622, søger helt tilbage til syndfloden med Noah og hans $æ$. $^{10}$

Stærkest i nyere tid står dog den islandske hypotese. Den kan dateres til Holbergs ungdom med den islandske historiker Thormod Torfæus' udgivelse af den danske kongerække, Series regum, 1702 (efter hans manus fra 1664, revideret 1690 ff. sammen med Árni Magnússon). Den videreføres med Holberg og Hans Gram samt Gerhard Schøning (jf. dennes fortale til Norges Riiges Historie, I, 1771, a 3r-b 1r) og afrundes i Danmark af P.F. Suhm (død 1798). Ifølge denne tese begynder Nordens oldhistorie med

9 På Egeløkke 20. december 1805 ejede Grundtvig Huitfeldt (i folioudgaven 1650-1652) og Meursius' Historia Danice 1630 (indbundet med sammes Ælnoth-udgave 1631, en udgave af De passione S. Caroli 1631 samt 2. forøgede og forbedrede udgave i 1631 af afhandlingen Roma Luxurians, sive, De luxu Romanorum, opr. Leiden 1605, jf. Grundtvigs auktionskatalog 1873, nr. 5629).

${ }^{10}$ Vinilandicus (2012) er langt den grundigste forskningsbehandling af Petrejus. 
Odin og asernes indvandring fra Asien nogle århundreder før Kristi fødsel, svarende til Snorres fortale til sin Edda ca. 1220. Endvidere går den ud fra, at islandske kilder er pålideligere end Saxo. Det fik den virkning, at tilhængere af Saxos prioritet hurtigt mindskedes i tal.

Men da den unge Grundtvigs asarus damper af i 1810'erne, begynder både han og oldforskeren P.E. Müller (1776-1834), den yngste teologiske universitetslærer i Grundtvigs studietid, at fremdrage Saxo på ny. Man var godt klar over, at Saxos krønike var mindst en generation ældre end Snorres Edda. ${ }^{11} \mathrm{Og}$ selv sammenholdt med en stor del sagaer er Saxos sagn ikke nødvendigvis lutter løs snak. I sit danske Sagabibliothek, I-III, 1817-1820, skelner Müller netop mellem sagaer med pålideligt historisk stof og dem, der holder sig til stof af mytisk eller fantasifyldt ("romantisk") karakter (jf. Steenstrup 1889, 109-111). Fællesskabet med Müller glædede den modne Grundtvig meget. Ved Müllers tidlige død i 1834 hilste han ham i et mindedigt (som dog først tryktes i hæftet af Danskeren for 16. juni 1849). ${ }^{12}$

Grundtvigs 1809-tekst bliver en optakt til hans Saxo-oversættelse. ${ }^{13}$ Grundtvig skønner dog endnu, at nordisk åndsudvikling er udgået fra Norge til Danmark og Sverige, for mellem Stærkodder i Liber VIII og Ottar Svarte i Liber X taler Saxo ikke om poesi, og uden poesi tror Grundtvig heller ikke, at man har nogen prosa. Dermed bliver der forskel på Norge, som vrimlede af skjalde, og resten af Norden. Altså måtte Absalon befale sin sekretær Saxo at skrive historie. Forskellen mellem Saxo og Snorre gøres kort og godt op til, at Saxo af Absalon fik pålagt at benytte latin, mens Snorre af egen drift og lyst skrev på modersmålet. Saxos stof er mekanisk sammensat af talrige uensartede smådele, men Snorre så sit som en organisk vækst, der fik ham til at glemme nutiden for at vandre i fortiden. ${ }^{14}$ Saxo disponerede på latin over en veludviklet retorik, men havde aldrig knælet i historiens tempel, mens Snorre genoplevede hedenold, som den var.

${ }^{11}$ Data på de to historikere anførtes i det oprindelige videnskabelige apparat til Vedels danske Saxo 1575 og Resens Edda 1665.

12 Digtet og dets baggrund er gennemgået i Lundgreen-Nielsen 2008, 237-250.

${ }^{13}$ G.L. Baden (1764-1840) kom derimod trods sin omfattende danske historieskrivning aldrig til at realisere en ny Saxo-oversættelse.

${ }_{14}$ Allerede Steffens opererede med det organiske over for noget mekanisk i sin 1., 5. og 6. filosofiske indledningsforelæsning i 1802. 
Det er uvist, i hvilken sammenhæng Grundtvig tænkte sig denne tekst trykt. Det håndskrevne titelblad ligner en pjeces. Sproget er akademisk, og han har anbragt hele 15 til dels udførlige fodnoter. Hovedtendensen er klart i Snorres favør, selv om en afsluttende paragraf høligt indrømmer, at Norge kan være stolt af Snorre, men at når dennes herlige frugttræ er visnet, kan Danmark glæde sig ved, at Saxos engang så syge og golde træ skal "grønnes mere yndelig og frembære de lifligste Frugter!" Det begrundes dog slet ikke. Måske er det ment som en forudsigelse om Grundtvigs egen fremtidige gendigtning af hele den nordiske sagnhistorie. Det virker, som om han ikke selv rigtigt tror på en sådan genkomst. Hans slutord klinger mere som en optakt til en forsonende fællesskål efter en civiliseret debat. Den slags var Rahbeks selskabelige specialitet, men aldeles ikke i den unge polemiske Grundtvigs smag. ${ }^{15}$

Fra samme tid stammer nogle forsøg på at oversætte partier af Saxo i Fasc. 241, stærkt påvirket af Schousbølles stil i Saxo-oversættelsen fra 1752 (Toldberg 1946, 106).

Sidst på året 1810 betragtede Grundtvig Absalon i digtet "Sorø Kirke” (i samlingen Nytaarsnat eller Blik paa Kristendom og Historie, 24. december 1810). Det er komponeret som digterjegets rundgang i kirken. Ved Absalons grav tiltaler han den døde biskop, der med sin bispestav aktiverede Saxo:

Med den det var, du Saxos Øie rørte,

Med den opmaned du den svundne Old.

Ja, Ædling, naar ved Valdemarers Minder,

Og naar ved dit opblusse mine Kinder,

Naar Øiet funkler ved en stor Bedrift,

Som du lod præge i den faste Skrift;

Og naar i Gru jeg gyse maa og blegne

Ved Tanken om, at var din Saxo ei,

Da maatte jeg, forvildet, uden Vei,

Omvandre her i Fædrelandets Egne.

(US II, 59-60) ${ }^{16}$

15 Endnu i sidste uge af oktober 1810 havde Rahbek og Grundtvig ikke truffet hinanden personligt i den dog lille hovedstad (Lundgreen-Nielsen 1980, 345).

16 "Fædrelandets Egne" betyder nok her 'de egne, hvor Absalon og Saxo grundlagde ideen om et dansk fædreland', et patria. 
Grundtvig besværer sig ikke over Saxos latinske sprogform, men lidt senere kommer dog en kritik af, at forskere som Torfæus, Stephanius, Ole Worm og Thomas Bartholin Thomæ Filius begravede de nordiske sagn og sagaer i afhandlinger på latin (64).

Endnu en poetisk kirkerundgang kom til i den utrykte, men bevarede tekst Roskilde, en versdigtning om gravmælerne i Roskilde Domkirke og deres betydning oplæst af kapellan Grundtvig ved det sjællandske landemode sammesteds i oktober 1812 (Fasc. 400.1). ${ }^{17}$ Ifølge øjenvidneberetninger var tilhørerne ikke umiddelbart henrevne af fremførelsen. Teksten behandles her under publikationsåret 1814 .

I sidste uge af 1812 udkom Grundtvigs første verdenshistorie, Kort Begreb af Verdens Krønike i Sammenhang (421 sider). Om dansk kultur i 1200-tallet hedder det ultrakort, at "ingensteds i Europa var Menneskeaanden paa den Tid saa hæderlig [dvs. ærefuldt] virksom som i det høie Norden" (US II, 234). Beviset er "Valdemarernes snilde Love" og "den Danmarks Krønike Saxo sammenskrev paa fint og kosteligt Latin", men fortsætter Grundtvig - et veritabelt "Under" er det på samme tid at se de fattige islændinge ivrigt "opdynge uvurderlige Skatte til deres Ætmænd" med Snorre Sturlesen i spidsen, hvis norske kongekrønike (Heimskringla) er "hartad mageløs". Under Christian IV meddeles knapt, at Vedel oversatte Saxo "paa kosteligt dansk" (271). Omkring 1700 skændte svenskerne på Saxo som "en ublu Løgner, uden at eie et Blad af deres Eget, som kunde modsige ham" (356). ${ }^{18}$ Fra dansk side syslede "Vorm, Bartholin og Resen" og Torfæus (360) med sprogkyndighed og sagaforskning, men beklageligt nok på latin; Stephanius, grundlægger af den videnskabelige Saxo-forskning ved sit kommentarbind 1645, er ikke med. Grundtvig synes endnu i 1812 at sætte den islandske tradition over Saxo.

Det ændres der ikke på i digtet "Ved Tyge Rothes Minde" i Grundtvigs politiske pjece Til Fadrenelandet om dets Tarv og Fare. Et Ord, 23. juli 1813. I strofe 3 taler Grundtvig bevidst kort om nordiske oldtidskrige og indrømmer, at "den, hos hvem en Snorro er oprundet, / Fra Saxos Amme

17 En komplet afskrift (dog uden tekstrettelserne) ved Svend Grundtvig fra 1881 er ligeledes bevaret (Fasc.401).

18 Dette gælder Olof Rudbeck (1630-1702) med Atlantica, I-IV, 1679-1702 (på svensk og latin) og hans göticistiske tilhængere. 
haver Prisen vundet" (og begge disse overvandt det i middelalderens historikerfag totalt "stumme Svithjod", Sverige) (US II, 701). ${ }^{19}$

Lige efter freden i Kiel udsender Grundtvig 1. februar 1814 RoskildeRiim, en udgave af digtningen Roskilde forøget fra 3444 til 7103 verslinjer, tilegnet Frederik VI. Det er en omhyggelig gennemgang af kirkens minder og de nutidige associationer, de udløser.

Ved Svend Estridsøns grav fremkalder Grundtvig mester Saxos "gamle Tunge" til at sjunge om bisp Vilhelm og kong Svends venskab til døden trods sidstnævntes synder (US II, 457); herefter sætter Grundtvig en selvdigtet ballade på 24 8-linjede strofer over Saxos beretning herom (Liber XI, 7.10-9.4). ${ }^{20}$

Senere følger et portræt af Saxo, skønt han dog ikke var gravsat i domkirken, men mindet ved en tavle med latinsk tekst i nordre tværskibsgavl. Den blev af Stephanius i hans Prolegomena til Saxo-kommentarerne 1645 (22-23) tilskrevet Lage Urne, der til sin død i 1529 var kirkens sidste normalt fungerende katolske bisp. At Saxos grav faktisk ikke kendes, får Grundtvig til at mene, at hans støv er blandet med "hver Ædlings Støv i Landet" (US II, 470), og at fremhæve, at han som "vort Danmarks Kongesmykke" kun er kendt for én bedrift, opsummeret i rimordet "Sagaskrift", så han "tilhører kun det Hele!”. Uden denne indsats ville Danmark have været "som en Myretue / Under Norrigs Kæmpefjeld", og folk kunne tro, at åndens kildevæld i Norden kun fremsprang "mellem Stene" i Norge, mens ingen blomster trivedes i Sjællands fagre lunde. På dette sted i 1814-trykket tilsætter Grundtvig i forhold til 1812-håndskriftet 40 verslinjer med yderligere tak til Saxo for hans "gæve Billedværk" (471). ${ }^{21}$ Herefter kommer dog en bebrejdelse over hans sproglige håndtering af de olddanske kilder:

Men, o Saxo! hvorfor vilde

Tid og Flid og Kløgt du spilde

19 Saxos "Amme" må vel i Grundtvigs billedsprog enten være Absalon eller kongeriget Danmark.

${ }_{20}$ Grundtvig lader kvadet være Saxos, hvad der er noget af en tilsnigelse (Frederiksen 1948, 124-126).

21 "Billedværk" er statuer, billedudskæringer, malerier og tegninger, så udsagnet er et af de få positive, Grundtvig har brugt om bildende kunster (se også i 1815 om Hamlets skjold, US III, 208, jf. Liber IV, 1.9). 
Paa at grave Danmarks Guld

Ned i stenet Romermuld?

Lad dets Gravskrift paa Latin

Klinge kostelig og fin,

Den kun Daarer kan erstatte

De i Grav forlorne Skatte.

Kunde du da ei fornemme,

Det var Synd at indeklemme

Rimene, som gik i Flok,

I den snævre Romerstok?

Kunde ei den danske Tunge

Tale, da den kunde sjunge?

(472).22

Grundtvig må altså lægge afstand til Saxo og hans samtid:

Da for Klerke, ei for Folket

Landsens Krønike Man skrev,

Da til Stads Man fint udtolked

Paa Latin, hvad Danske drev.

(472-473)

Men han hader dog ikke Saxo herfor. "Venlig" (473) vil han tage afsked med ham her:

I dit Hjem, og over Støvet,

Som tilhyller Rosenløvet,

Dansk og trofast Broderhaand

Rækker jeg med Vennetaarer

Dig og bolde Absalon!

Tidens Aand os alle daarer,

Og din Alders Aand i Rom

22 Ordet "Daarer" skal læses som hensynsled ("for dårer"), "forlorne" er en germanisme for "tabte", og "Romerstok" betyder "latinsk gabestok eller ditto fængsel". De to sidste verslinjer har i originalteksten fra 1812 et afvigende retorisk spørgsmål: "Var da Danmarks Tungemaal / Hundeglam og Ugleskraal" (v. 1444-1445). 
Havde jo sit Fyrstendom.

(473)

Slutvurderingen af Saxo bliver, at "Gud din kløgtige Latin / Gjorde til en Salve fin, / Som bevared Danmarks Lig", og aflokker Grundtvig en profetisk anelse: "Ak, maaske skal vore Navne / Og engang hinanden favne". ${ }^{23}$

7. oktober 1814 følger et nyskrevet kommentarbind, Roskilde-Saga, der dog frigør sig mere og mere fra den tekst, den egentlig blot skulle hjælpe til forståelse af. Ved Absalons initiativ med en Danmarkshistorie skrevet i det Sorø kloster, han selv stiftede, lufter Grundtvig en principiel skepsis over for historieskrivning, fordi den kan være et varsel om død, ligesom når en gammel mand gør testamente, bestiller sin kiste og formulerer sin egen gravskrift. Grundtvig foretrækker nu levende mundtlige minder til inspiration for kommende slægter. Men Absalon fandt altså Saxo og bestilte ham til at skrive. ${ }^{24}$ Grundtvig opridser den historiske situation. Sven Aggesen, Saxos eneste forgænger, ville klogelig nok gøre en kort fremstilling med "skarpe Omrids" (US II, 640) ud af mange forskellige oplysninger. Saxo derimod ville bevare så meget som muligt af det brogede stof, for selv hvis det gav et forkert billede af det skete, havde oldtiden troet på det og opbevaret det i fortalt form. Det er et bevidsthedshistorisk argument fra Grundtvigs side.

Saxos latinske sprogføring skulle endvidere for både omverdenens og efterverdenens lærde mænd demonstrere, at danskerne havde tilegnet sig Guds ord så vel som det latinske sprog. Saxos tekst kan således "fuldelig sandfærdig" (640) sammenlignes med "Skattes Nedgravning", for hvis ikke man havde tvivlet på menigmands interesse for forfædrene, "havde Saxo visselig ei meer end Snorro kaaret Roms Tungemaal" til sin historieskrivning, mener Grundtvig. Af det forkerte fremmedsprog vildledes man såvel om de hjemlige byer som om de gamles fædres "Handler og Tale og Kvad, da meget maatte underlig dreies og tit forvendes, inden det pynte-

${ }^{23}$ Derpå genoptager digterjeget sin forevisning af domkirkens minder ved sarkofagen med dronning Margrethe, en ret Nordens amazone, hvis Kalmar-union hen over hovedet på de tre nordiske folk Grundtvig ikke synes om.

24 Trods genrebestemmelsen "Saga" skriver Grundtvig ikke sine forklaringer i norrøniserende sagastil, men benytter en arkaiserende krønikediktion à la Vedel, der forudsætter et kendskab til ældre dansk. Det havde det almindelige læsende publikum næppe i 1814 og har det slet ikke i dag. 
lig kunde udtrykkes i det Tungemaal, som vidste kun lidt af Saadant at sige". Gevinsten er en grundig og rigtig skildring af "de Danskes Levnet i Synderlighed”, for skønt islænderne overgår Saxo "i hjertelig Sødhed og høi Enfoldighed", har disse klippebørn "ikke saa sjelden med halve Øren fornummet, eller og seet paa Skraa”, når det gjaldt danskere. Grundtvig må dog indrømme, at "Knytlinge Saga, som taler om Knud og hans Ætmænd, taler ret, som en Broder mon sømme, og at Saxo taler imellem langt mere uskikkelig om Nordmænd, end Snorro om Danske, og ophøier mangengang sine Landsmænds Dyd og Kongernes Vælde vidt over det, som tilbørligt er" (640-641). Men "nu kan vi lade de Gamle smukt rette hinanden" (641) og spare vore nutidige "Ukvemsord" om deres fejl.

Sluttelig undrer Grundtvig sig over, at en mand som Saxo kunne blive så rent glemt, "at Ingen kan sige, hvorfra han var, eller bære os nogen Tidende om ham" (641). Altså var han som den sidste overlevende i en by, der kan rejse gravmonumenter for alle andre, men selv ikke får et. Det var ved en Guds førelse, at "Landsens Krønike blev beskrevet, der det var den høie Tid", og at Saxos "Leiestæd, som vi det kunde vente, er i Roskilde Kirke, det er os overantvordet”. Det sidste, der ikke længere står til troende, har Grundtvig læst i Vedels Fortale til Saxo-oversættelsen, 1575 (B iv r). ${ }^{25}$ Roskilde-Saga har i øvrigt en del fodnoter med henvisninger til Vedels Saxo-tekst.

\section{Saxo-rusen i foråret 1815}

Bestillingen på at oversætte Snorre kommer den 6. juni 1812 glidende til Grundtvig fra norsk side, hvor den dog kun gjaldt de indlagte kvad i Heimskringla. Efter 13. maj 1813, da den udpegede oversætter af Snorres prosa, filologen Paul Arnesen (1776-1851), opsagde sin medvirken, ændredes aftalen til hele teksten. Kieler-freden i januar 1814 skilte Norge ud fra dobbeltmonarkiet, men Grundtvig besluttede at fortsætte arbejdet på Snorre, blot under et nyt udgiverselskab for nordiske oldskrifter stiftet 3 .

25 Vedelas forveksling af historikeren med en domprovst ved samme navn ca. en generation tidligere gentages af Stephanius (1645, Prolegomena, 9 og 15-18). Stephanius har også samlet udtalelser fra lærde, der beskylder Saxos sagnhistorie for at være løgn, forkerte oplysninger eller dennes egne opdigtninger (35-37); her er det poetiske hos Saxo følgelig udelukkende negativt. 
august 1815 i stedet for den på samme dag nedlagte københavnske afdeling af Det Kongelige Selskab for Norges Vel. Til ledere valgtes foruden Grundtvig den norskfødte digter og embedsmand C.H. Pram og juristen F. Treschow (1786-1869), hvis fader var norsk, mens han selv var elev af juristen A.S. Ørsted og allerede blev højesteretsadvokat som 25-årig.

Det nye oldskriftsselskab har fra første færd en tidssvarende Saxo-oversættelse med blandt de oplagte emner. Medlemmerne håbede formentlig på, at adskillelsen mellem Danmark og Norge kun var midlertidig, så Snorre på dansk også stadig var berettiget. Under Napoleonskrigene havde offentligheden vænnet sig til, at europæiske riger ændredes, grænser flyttedes, og herskere udskiftedes.

Grundtvigs inspiration til at oversætte Saxo opstår før hans medvirken i oldskriftsselskabet. Den skyldes en personlig gennembrudsoplevelse, som han første gang har berettet om i sin fortale til Saxo I, 1818. Just da han i begyndelsen af januar 1815 var nået midt i Olav den Helliges saga i sin Snorre-oversættelse, "da faldt det mig som en Steen paa Hjertet, at jeg sad der og udtømde mine Kræfter over Norges Krønike, der nu ikke længer kiærlig sammensmeltede med Dannemarks" (US IV, 96), medens Saxo lå "tildeels ukiendt og uændset, tildeels ogsaa miskiendt og forhaanet! Fædrenelands-Kiærligheden vaagnede med en mig hidindtil af Erfaring ubekiendt glødende Ild og seierrig Vælde i mit Bryst; sønderrive det historiske Baand mellem Dannemark og Norge, som fra Barnsbeen gjorde Eet i min Forestilling, det hverken kunde eller vilde jeg, men til at skielne bestemt imellem Dansk og Norsk havde ikke Sværdslag men Iisslag nødt mig, og jeg kunde nu ei bære det over mit Hjerte at udgive Snorros Krønike, med mindre Saxos kunde følges med!". ${ }^{26}$ I en utrykt Indbydelse til Pronumeration paa Nordens Historie ca. $1824^{27}$ vender Grundtvig tilbage til denne oplevelse ved om den nu færdige kombinerede Snorre-Saxo-oversættelse at skrive: "En stærkere Følelse end jeg kunde modstaae, og dybere, end jeg har lært at lodde, var det som bestemde mig til at begynde fra denne Side, der ellers var langt fra at være den mest tiltrækkende for en saa magelig

26 "Sværdslag" er regulære krigshandlinger, "Iisslag" den isnende modvindsnedbør i ubarmhjertig storpolitik.

27 P.E. Müller drøftede netop i 1823 Saxos hedenske sagn over for de islandske sagakilder i to afhandlinger behandlet i Det Kongelige Danske Videnskabernes Selskab og trykt der som Critisk Undersogelse af Danmarks og Norges Sagnhistorie eller om Trovardigheden af Saxos og Snorros Kilder (313 sider). 
Skribent som jeg" (Fasc. 230.4, 2). At han beretter om sit gennembrud i et privat manuskript syv år senere, er et bevis på ægthed.

Vel kalder Grundtvig ikke direkte sin ændrede holdning til Saxo for en rus, men hans signalementer stemmer med en sådan. Grundtvig etiketterede retrospektivt og afstandtagende sin eksistentielle ungdomsbegejstring for nordisk mytologi som "Asaruusen" i et utrykt manus fra 1814 (Fasc. 179, 4r) og derpå siden på tryk i tilsatte selvkommentarer ved optryk af ungdomstekster i Kvedlinger, 1815. Ordet og begrebet overtages efter hans død af grundtvigianere og derpå af Grundtvig-forskere. Da islænderen Grímur Jónsson Thorkelin (1752-1829) i begyndelsen af juni 1815 fra København udgiver det angelsaksiske Beowulfskvad for første gang på tryk sammen med en ret fejlfyldt nylatinsk oversættelse, angribes han af Grundtvig i en avispolemik. Den ender dog positivt med, at den velhavende adelsmand Johan Bülow fra Sanderumgård på Fyn bestiller Grundtvig til at oversætte dette epos til dansk. Sin vilje til at behandle dette minde om fortidsnordboerne betegner Grundtvig i det trykte bidrag “Om Bjovulfs Drape" som "Elskovs-Rusen" (Danne-Virke, II, 1817, hæfte udsendt 22. april, 211). ${ }^{28}$

Resultatet af Grundtvigs Saxo-feber er i alt fald, at han den 14. april 1815 tager fat på at fordanske Saxos 1. bog (Fasc. 241 og 242) og ikke standser før 1822, da hele teksten foreligger på hans dansk. Og dermed har han definitivt fundet frem til Saxo.

Allerede 9. september 1815 fulgte Grundtvigs hæfte Prøver af Snorros og Saxos Krøniker i en ny Oversattelse med et Ord til Danske og Norske (132 sider). I en indledende "Mindesang paa Fædres Gravhøi” appellerer han til moderne danskere og nordmænd om at elske forfædrene og fædrelandet med henvisning til Jesu tiltale af de sovende disciple i Getsemane have (Markus 14.37, men ordret lånt fra begyndelseslinjen til en påskesalme af Kingo, 1689, SS IV, 1941, 284) (str. 12) og til profeterne Esaias (52.8) og Hoseas (8.1) (str. 17-18). I en fortale dateret 20. august præsenterer han Saxo og Snorre som et par - i kronologisk orden - og derpå sine egne oversætterforgængere Vedel og Peder Claussøn Friis (US IV, 16-17). Undervejs får han også korrekset nordmanden Gerhard Schøning for at have peget

${ }^{28}$ Grundtvigs gendigtning på 263 sider - der blev den første på et moderne europæisk sprog - samt en indledning på 74 sider og et apparat på 58 sider (begge på dansk) udkom 7. august 1820 . 
fingre ad Saxo (20). ${ }^{29}$ En ordret oversættelse, som historikere kan betjene sig af i stedet for originalerne, er det ikke, Grundtvig indbyder til, "da Ingen bør vove sig til at være nordisk Historieskriver uden selv at forstaae saavel Islandsk som Latin" (22). Han vil derimod levere Saxos og Snorres skrifter med bevarelse af "deres eiendommelige Aand, i et let, fatteligt og trohjertigt Sprog”, således som Vedel og Peder Claussøn også gjorde i deres tid. Han indrømmer, at han måske har taget sig for stor frihed i gengivelsen af de indlagte verstekster, men det sker efter "modent Overlæg" (23) og med god vilje. De tabte kvad, Saxo gendigter, har jo været på gammelt dansk, Grundtvigs versioner er "virkelige nydanske" i versmål og ord. Begge hans forfattere var problematiske verskunstnere, Snorre på grund af de fastlagte billedudtryk og omskrivende ordlege i norrøne skjaldedigte (dvs. kenninger og heiti), Saxo på grund af den store afstand mellem antik latinpoesis bredde og nordiske sprogs kortformer. Forklaringen bliver især indviklet ved Saxo, fordi de kvad, denne har kendt på dansk, tabte ved at få tilsat en fylde af latinske udsmykninger, hvorpå Grundtvig "med Hjertensfryd” lover at befri dem for "det latinske Snørliv og Krumlæg [dvs. krumslutninger]”, så de kan ånde frit og rette benene ud (24).

Senere i hæftet ved fremstillingen af Hagbards og Signes kærlighed (Liber VII) indrømmer Grundtvig i en lang fodnote, at en længere replik fra Signe på Saxos latin er prosa, men dem har han "sat på Vers" (63), for de ikke skal lyde tomt og svulstigt som et afmægtigt referat af poesi. Han vil - frit - "give Talens Indhold i de bedste Riim og Lignelser, jeg kan faae fat, med Øret vendt mod Oldtids Røst”. Det er et smidigt kriterium.

I sin fortales slutsætninger påberåber Grundtvig sig støtte fra hver “ærlig Mand” og velsignelse fra Gud til at undgå “de selvgjorte Lærde og Kloge med Sværtekrukken og Roestrompeten” (25). Et fromt ønske, som ikke skulle gå i opfyldelse.

Redegørelser for Grundtvigs borgestuestil og for subskriptionsprojektets skæbne, da tre bind Saxo og tre bind Snorro forelå færdigtrykt, er at finde andetsteds og gentages ikke her. ${ }^{30}$ Forståeligt nok var Grundtvig undervejs i sin lange solooptræden til tider træt af det daglige slid, skønt skiftet mellem norrønt, angelsaksisk og latinsk sprog må have været en

29 Bramfri Saxo-kritik ses f.eks. i Schøning 1771, 110, 166, 171-172, 192, 207 og 1773, 219.

30 Lundgreen-Nielsen 1980, 831-849; diverse bidrag i Jørgensen, Friis-Jensen, Mundal 2010 ajourfører positioner og litteraturhenvisninger. 
opmuntrende frihed at tage sig. Nogle indledende sider i et indlæg i den litterære københavnske tylvtefejde i efteråret 1818 mellem Oehlenschläger-beundrere på den ene og alliancen Grundtvig-Baggesen på den anden side markerer tydeligst Grundtvigs triste fornemmelse af i levende live at være død for nutiden (US III, 624-626).

\section{Saxo i Grundtvigs digtning og læsning fra 1815}

Sidst i 1815 udkommer Grundtvigs digtsamling Heimdall. Dansk Nyaars-Gave for 1816 med "Et Blad af Jyllands Rimkrønike" (en lang Jyllandshistorie på 270 strofer à 7 jambiske verslinjer). Saxo (og den af ham afhængige Rimkrønike) er her hovedkilden til den jyske hedenske periode. De fremtagne nøglepersoner er Frode Fredegod med slægt (Liber V), Rolf Krage (Liber II), Amleth (Liber III-IV), Vermund og Uffe hin Spage (Liber IV) og Regnar Lodbrog (Liber IX). De illustrerer folkepsykologiske egenskaber, som Grundtvig vil fremhæve - og han respekterer derfor ikke Saxos kronologi på dem. I digtet "Høstgildet” til dronning Maries fødselsdag 1815 indfører Grundtvig sit symbol på historisk erindring: "Saxo den Kiærminde-Have / Lukkede med Romer-Stave, / Nøglen dog har Danmark giemt" (US III, 251), altså et løfte om hans kommende danske oversættelse.

Et bidrag i Danne-Virke III med titlen "Et Par Ord om Oldgrandskning” (hæfte af 27. august 1817) er endnu et opgør med asarusen og slutter med at konstatere, at de islandske sagn er "ligesaa usikkre og blandede som Saxos" (US III, 524).

Grundtvigs opvurdering af Saxos tekst i forhold til de islandske kilder betyder ikke, at han regnede alle Saxos beretninger for så ægte historiske, som denne - måske - selv havde gjort. I de år, Grundtvig arbejdede mest intenst med Saxo, stod han som forfatter til tre verdenshistorier på i alt 1.769 tryksider og kendte også som underviser på Egeløkke og for Schouboes Institut en hel del til det praktiske historiefags farer og fælder. Konkret tager han i fortalen til sit Saxo-bind I, dateret 12. september 1818, stilling til Saxos sagnhistorie med en udtrykkelig forsikring om, "hvor langt det er fra mit Ønske, at indbilde Nogen, man kan fæste Troe til saa blandet og tit forvirret en Tale, som til et Evangelium" (US IV, 94). Grundtvig har således klart sagt, at han ikke er Saxo-fundamentalist. 
Han understreger på tryk i 1818, at selv hvis et sagn skulle være ren digtning, har det dog bevæget folkets hjerte, siden det er blevet husket (og til sidst nedtegnet på latin af Saxo). Er en berettet handling ikke historisk, fortsætter han, beviser sagnet om den, at folket har fundet den troværdig og sat den højt, og det ville ikke være tilfældet, hvis folket ikke selv kunne have handlet på samme eller tilsvarende vis. Hovedsagen for Grundtvig er således, at alt, hvad der fortælles, gives videre og overlever, må regnes for et ægte vidnesbyrd om folkets sind ("Hjertelag" er hans ord) - "om Sagnet end tager nok saameget Feil i Henseende til Navn og Tid og andre Bi-Omstændigheder". Vinklen er fortsat bevidsthedshistorisk og dermed forskellig fra, hvad Grundtvig undertiden betegner som "den rene Historie" eller "reenhistoriske" ${ }^{11}$ udsagn, der udelukkende omhandler det, der kan dokumenteres.

I sin afrunding af 1818-fortalen ser Grundtvig nok, at Saxos fremstilling fra og med Gorm den Gamle både må suppleres og korrigeres i henhold til moderne forskning (f.eks. P.F. Suhms). Saxos værk i den alt for bredt affattede del om hans egen tid er desuden præget af, at han levede og skrev under Valdemar den Store og Absalon med disse som direkte kilder. Grundtvig indrømmer også, at det er vanskeligt at se bort fra "Saxos aldeles udmærkede Evner" (103), for kun et sjældent opvakt hoved kunne i det 12. århundrede "opnaae den Styrke i det fremmede Sprog, den Klarhed i Begreberne og den Kunst i Fremstillingen, som her unægtelig findes”. Sammenfattende kan Saxo ikke kaldes "en Mester i historisk og poetisk Kunst", men er dog "et Dansk Vidunder" i sin tid som "en sund og kraftig, kiærlig og forstandig Historie-Skriver” (103-104).

Grundtvigs nuancerede karakteristik tåler at sættes op over for tendenser i det 20. århundrede til at degradere Saxo til betalt propagandist og manipulator. At Saxo i udformningen af sin krønike også har benyttet islandske kilder og var dybt afhængig af sin levetids stormænd, behøver vi ikke lære af senere kritiske historikere. Det står med rene ord i hans egen fortale.

B.S. Ingemann skulle 12. april 1818 begive sig ud på en toårig statsbetalt rejse med et længere dannelsesophold i det katolske Rom. Grundtvig offentliggjorde et både formanende og advarende afskedsdigt til ham betitlet "Kiærminde-Bladet" (Danne-Virke IV, oktober 1818). I en fremmaning

${ }^{31}$ F.eks. i 1847, Bugge, II, 1968, 248. 
af den moderlige danske nationalånd bruger han blandt andet billedet, at "Saga laae paa Saxos Pergament" som et "Liig paa Baare" (str. 25, US III, 549). Denne karakteristik modarbejder han senere (str. 35-37, 550551) med antydninger af, at hans nye danske Saxo-oversættelse vil vise, at historiegudinden Saga (fra eddadigtet Grimnismál str. 7) nok sover "dødningbleg" (str. 48, 553), men endnu kan oprejses “ved et Under”, om Gud vil. Digtet optrykkes i Nordiske Smaadigte 1838.

I Bjowulfs Drape. Et Gothisk Helte-Digt fra forrige Aar-Tusinde af AngelSaxisk paa Danske Riim i 1820 har Grundtvig i den kombinerede "Indledning og Fortale" seks gange kort konstateret, at Saxo ikke synes at have kendt denne tekst. ${ }^{32}$ Sit Beowulf-projekt annoncerede Grundtvig allerede i Danne-Virke II, hæftet af 24. april 1817, i artiklen "Om Bjovulfs Drape eller det af Hr. Etatsraad Thorkelin 1815 udgivne angelsachsiske Digt" (207-289). Han har tre Saxo-vink. For det første minder uhyret Grændel ham om den kæmpeslange, som i sagnet om Regnar Lodbrog vogter den østgotiske konge Heroths datter Thora (248, note *, jf. Liber IX, 4.5-4.7). For det andet finder Grundtvig med opregning af ni angelsaksiske navne svarende til danske skjoldunger (281), at Bjovulf-skjalden synes at være bedre hjemme i den danske end i den svenske og gotiske historie. For det tredje undrer Grundtvig sig over, at intet nordisk sagn overhovedet kender til helten Bjovulf, men foreslår, at hvis man af-angliserer navnet, er der "maaskee et Stykke af ham i Saxos Boe" (287, dvs. Bous i Liber III, 4.134.15). Det sidste er et usandsynligt gæt (jf. Davidson 1980, 58).

Bind 3 af Saxo-oversættelsen i 1822 indleder Grundtvig med et digt uden titel (US IV, 183-188). Her hyldes Saxo for sin ømhed over for det ældgamle Danmarks ære (str. 1), begrundet $\mathrm{i}$, at danskerne længtes ud over det timelige og fulgte "Evigheds-Strømmen i Tidernes Bølger" til "Kjærligheds Øe" (str. 2) med "Livets og Kjærligheds Væld" (str. 3), som endda er "oprundet af Paradis-Minde" (erindringen om Edens have). Men modsat Snorres Norge er Danmark præget af "en vidunderlig Paradis-Kvinde" (str. 3-5), som kendes fra Saxo (Liber I, 8.14 om kong Hadings ridt med en kvinde i underverdenen lige til den lukkede indgang til evighedslandet efter døden). Det bliver en pointe, at hvor Snorre skildrer individuel mandsære og heltedød, foretrækker Saxo den kærlighed, danskerne bar i

32 XXXVII, XL, LV, LIX, LXII og LXXIII. 
hjertet ved at gøre digteren Hjarne til konge (Liber VI, 1.1-1.2), ${ }^{33}$ og den ukuelige fædrelandskærlighed, som Absalon og Saxo dyrkede i henholdsvis dåd og digt. Foruden Grundtvigs eget optryk med den tilsatte titel "Saxos Minde" i Nordiske Smaadigte 1838 forekommer digtet i forskellige kortere versioner i antologier og læse- eller sangbøger ved grundtvigianske redaktører. Det kan således anses for Grundtvigs varige vurdering af Saxos indsats.

Efter den fuldbyrdede oversættelse af Saxo og Snorre i de to gange tre bind var udsendt 1818-1823, indrykkede Grundtvig en erklæring i Nyeste Skilderie af Kjøbenhavn 9. august 1823 om, at han havde lyst til at fortsætte Danmarkshistorien fra 1186, hvor Saxo sluttede den. ${ }^{34}$ Han nærer et ønske om, "at det skal lykkes mig, her som hist, naar det Største griber mig, da at dæmpe Begeistringen, og lade den, dæmpet, udbrede sig over det Hele; at opløse det Sprog, hvori jeg taler helst om de forrige Dage, og skjule dets Kierne i de enfoldigste Ord, som Umyndige fatte. Det, føler jeg, det, kan jeg forstaae, er Folke-Livets Tarv" (US IV, 195). I forhold til hans krønikeprosa må det angive et stilskift, som dog aldrig realiseredes. Fra april 1821 var Grundtvig uden ansøgning blevet præst og skrev på omfattende teologiske afhandlinger og på salmer, til han som injuriedømt frivilligt forlod sit kald i statskirken i maj 1826.

Disse års markanteste værk er den store både personligt bekendende og alment profetiske digtning Nyaars-Morgen. Et Rim, 1824. I fortalen - dateret 12. august 1824 - lægger Grundtvig afstand til Saxo ved en forbløffende betegnelse af hans værk som "Forhaanelsen af Modersmaalet $i$ vor Moders egen Krønike" (US IV, 247) og indrømmer, at han har selv været meget sen til at søge at opnå et "kjærligt Ægteskab mellem Edda og RimKrøniken”, altså forbinde en ældre nordisk slægtsfølelse med en senere indpodet danskhed. Ligesom kongesønnen Gorr (i Fornjótr ${ }^{35}$ ) måtte Grundtvig fra det højeste Norden "seile længe, før jeg fandt mine Frænder paa de Danske Øer, mine Helte hos Saxo, og mit Valhald i Rim-Krøniken”. I

33 Ti år senere i Nordens Mythologi 1832 forstår Grundtvig dog Hjarne som "Skjalde-Aaren" i Norden, altså en betegnelse for digterevnen mere end for en virkelig historisk person (US V, 664).

34 Jf. Vedel 1575, DXL, gentaget i Stephanius 1645, 252.

35 Grundtvig havde behandlet denne tekst ud fra et anonymt læserbrev i DanneVirke, III, 1817, 190-200. Den udkom i øvrigt netop i 1824 i en dansk oversættelse med kommentarer ved C.C. Rafn. 
den i helhed utrykte tekst Glar-Øine (Fasc. 388.88), en alfabetisk ordnet kommentarliste til Nyaars-Morgen, undres Grundtvig over, at grammatikeren Saxo kan genfortælle hedenske oldsagn med samme omhu og engagement, som han ofrer på katolikken Absalons heltegerninger. ${ }^{36}$ I selve digtet tildeles Saxo - med navns nævnelse - kun strofe 235 (af i alt 312, US IV, 320) som lydig historiker for Absalon (“Axel”) og redningsmand af Danmarks ære. Ved denne tid, husker Grundtvig langt senere i KirkeSpeil, 1871 (foredrag fra 1861-1863), herskede der i Danmark ligegyldighed for alt åndeligt og for fædrelandet. Man sagde efter hans fortale til Nyaars-Morgen spydigt, at han nok snart ville udvandre med Saxo under den ene arm og Snorre under den anden (US X, 349). ${ }^{37}$

I den i helhed utrykte teologiske brevveksling mellem en hovedstadspræst og en brav nørrejyde - en art brevroman fra 1824 - omtaler Grundtvig "Saxos og Snorros halvhedenske Folke-Krøniker, og et ditto angelsachsisk Æventyr" (Beowulf) (US IV, 234), som han tændte "Nat-Lampen" (235) over engang, altså studerede i døgndrift.

Samme år, 1824, fremstillede Grundtvigs nyvundne penneven B.S. Ingemann Saxo - under navn af "Mester Lange" - som en kejtet olding til hests, der længes efter sin studiecelle, ideligt taler latin og har spændt sværdskeden på, men glemt sværdet og i øvrigt falder klodset med sin hest ned i snedriver. ${ }^{38}$ Det fik Grundtvig til at korrekse vennen i et lille privat digt tilsendt ham 3. juli, hvori han anholdt beskrivelsen af Saxo som "en Filister" og "en naragtig Pedant" (Grundtvig 1882,13). Ingemann hævdede i et svarbrev af 8. juli fra Sorø med fuld anerkendelse af Grundtvigs sagkundskab på Saxo kun at have villet individualisere denne som menneske, men uden nogen ond vilje over for den rene ånd, der udmærkede hans genius. Han forestillede sig, at den gamle Saxo i det ydre må have haft nogle af et

36 Karakteristikken af Saxo fra Glar-Øine er trykt i helhed i Begtrup 1901, 219-222.

37 Grundtvig overvejede både før, under og efter censur-årene 1826-1837 at udvandre - til Norge, Tyskland, England eller USA. Hans søn med Marie Toft, Frederik Lange Grundtvig (1854-1903), realiserede en amerikansk emigration fra 1881, men vendte i 1900 hjem nedbrudt af sygdom for at dø kun 49 år gammel. 38 1.-3. sang af den episke (vers)digtning Waldemar den Store og hans Mand, juli 1824. Ingemanns primære kilde til skildringen var formentlig det indtryk, han havde fået fra gennemlæsning af Sejer Schousbølles Saxo-oversættelse 1752 (Galster 1922, 37-39). I sin fortale til Snorre-oversættelsens bind I, 1818, kalder Grundtvig Schousbølles tekst "en Forhutling af Saxos Bog”, hvormed forlægger A.H. Godiche "hjemsøgde" Danmark (US IV, 164). 
klosterlivs og lærd stuelivs lader og manerer, som var modsat heroismen i et ridderliv. Grundtvig svarer 9. juli fra København, at Ingemann er "stokblind for Saxos Værd” (17), når han gøres til “en tør Annalist” på baggrund af det "lige saa vel i poetisk som i lingvistisk Henseende mageløse danske Underværk fra vores Middelalder”. Grundtvig indrømmer dog, at han måske selv inderst inde føler sig som "en Gjenlyd af Saxo" (18) i sin samtid. I Ingemanns Saxo aner han derfor et angreb på "det virkelig eller tilsyneladende bagvendte og pudserlige”, der var træk i hans egen personlighed (18). Grundtvig foreslår, at navnet under Ingemanns forfejlede portræt af Saxo rettes til "Svend Aagesen" (20) (Aggesen), fordi dennes kortfattede danmarkshistorie netop sprang oldtiden over til fordel for Valdemarstiden. I et følgende udateret brev accepterer Ingemann et "Sueno Agonis" (22), skønt han stadig er uenig i Grundtvigs tolkning af hans Saxo-figur og bestemt nægter, at den skulle latterliggøre Grundtvigs psyke. ${ }^{39}$

Efter sine egne trykte oversættelser fortsætter Grundtvig med utrykte overvejelser over forskningens stade. I "Om Oldsagnene hos Saxo" 18231824 hedder det om andsen halvdel af det 18. århundrede, at "Islanderiet med hele sin storagtige Overtro og Smagløshed herskede dengang i nordisk Oldgrandskning, alt Islandsk var ypperligt, og selv de usleste Ammestue-Sager fra Island var i det Mindste rimeligere end hvad der kun havde sin Hjemmel hos Saxo" (Fasc. 267.2, 1v); Suhm vovede næppe at forsvare Saxo og angreb kun de islandske kilder, som også blev regnet for upålidelige af islænderne selv. Efter Grundtvigs fortsatte bevidsthedshistoriske forståelse ligger værdien af sagnhistorien ikke i præcis (men tilfældigt foranlediget) datering af begivenheder eller identifikation af personer, men i, at de har "endog i deres største Vilderede ubetaleligt Værd, som paalidelige Mindes-Mærker af det Folks Aand og Hjerte og Bedrift, som de tilhøre" (2r). I et fragment af en indbydelse til en Nordens historie indrømmer han, at oldsagnene ikke indeholder "meer Historisk end hvad de unægtelig selv udgiøre: et usvigeligt Vidnesbyrd om, hvilke Forestillinger vore Fædre for et tusind Aar siden gjorde sig om Nordens Fortid, og hvad der i deres Øine var Stort og Elskeligt, Mærkværdigt [dvs. værd at lægge mærke til]

39 I et langtrukkent rimbrev "Trøstebrev i Sorgen over Kong Valdemar og hans Mænd” i Nyeste Skilderie af Kjøbenhavn i november 1824 (US IV, s. 345-364) under det Baggesenske pseudonym "Giengangeren” forsvarer Grundtvig dog på historiens vegne Ingemann imod en skarp kritik fra Chr. Molbech i Nyt Aftenblad fra oktober 1824, men uden at komme ind på Ingemanns forvrængning af Saxos person. 
og Poetisk” (Fasc. 230.5, 3-4). Alligevel må ethvert andet europæisk folk $ø$ nke at have en sådan "lererig Baggrund" for sin historie.

Det står fast, at Saxos nordiske oldsagn lader sig forøge og belyse ved hjælp af gamle islandske bøger, men også at "Islændernes Taushed paa ingen Maade gjorde Saxos Ord til Snak, og at deres Modsigelse maatte understøttes af forsvarlige Grunde, hvis Saxos Ja ei skulde være ligesaa godt som deres Nei” (Fasc. 256, fra 1823 eller 1824, 1v-2r). Grundtvig erindrer samtidig om, at Saxo levede midt i det 12. århundrede, og at der næppe findes en islandsk bog, der er så gammel. Nordiske forskere burde derfor slutte fred, så islandsk og dansk kildemateriale enigt anvendes til afvisning af tyske forskere, der forsøger at tilegne sig begge og germanisere dem. Grundtvig tilføjer, at Stephanius indledte et sådant samarbejde i sine Saxo-kommentarer Note Uberiores, 1645, hvor private breve til ham fra Brynjólfur Sveinsson (1605-1675) på Skálholt blev citeret for oplysninger fra den islandske overlevering af mytologien. ${ }^{40}$

Grundtvig ser det som et generelt problem ved norrøn filologi, at den lærde europæiske verden er fikseret på antik græsk og latinsk kultur i poesi, historieskrivning, mytologi og sagn, og i Norden anerkendes tilmed først og fremmest det, der ytres i den nutidige tyske forskerverden. Den er dog karakteristisk ved hverken at kunne eller ville læse dansk og islandsk. ${ }^{41}$ Undtagelsen er J.G. Herder, som derfor ikke ænses af de tyske universitetsfilologer (Fasc. 251, 3r-v).

Den 6. marts 1829 udsendte den embedsløse og censurerede Grundtvig sin måske originaleste digtsamling, Krønike-Riim til Børne-Lardom på 187 sider. ${ }^{42} \mathrm{I} 47$ af i alt 52 digte fortæller historiske personer, steder og kræfter i “jeg-" eller "vi”-form uden vanskeligt billedsprog om sig selv i

40 Stephanius har også 16 gange trykt henvisninger fra den gamle lærde Arngrímur Jónsson (1568-1648).

41 Goethe, der ikke så andet poetisk brugbart i nordisk gudelære end den selvironiske humor, læste således som purung om aserne på fransk i Mallets danmarkshistoriske værker fra 1750 'erne og siden, vejledt af Herder, på latin i Resens Snorres Edda, Hávamál og Völuspà, 1665. I Goethes erindringer Aus meinem Leben. Dichtung und Wahrheit (III, 1814) kaldes de "Nebelbilder, ja bloße Wortklänge" (Goethe 1967, 537), beslægtet med Ossian-sangene.

42 Titlen signalerer genren rimkrønike, hvis ærkedanske version fra $1495 \mathrm{C}$. Molbech havde genudsendt i december 1825 i en videnskabelig udgave. Den anmeldte Grundtvig kritisk og omhyggeligt i Nyt Aftenblad 1. april-6. maj 1826 på baggrund af udførligere håndskriftlige arbejdspapirer (Fasc. 288.1-6). 
vendinger, som umyndige er i stand til at forstå (og endda måske kan lære udenad) ${ }^{43}$ Historikeren Saxo får dog kun tre linjer i digtet "Danmark" (Grundtvig 1875, 212); den her nævnte Hrodgar er identisk med kong "Roe", Roskildes grundlægger Roar (Liber II, 5.2), og Saxos stil kaldes runestave i kampesten snildt indprikkede med romerpren [dvs. griffel]. I noterne er der en "Anmærkning" på opslagsordet Danmark, der henviser til Saxos krønike for overleveringen af oldsagn, der kan "smykke Fædres Grave med levende Blomster" (Grundtvig 1875, 238, note 1).

Nordens Mythologi eller Sindbilled-Sprog, historisk-poetisk udviklet og oplyst, udsendt 22. december 1832, bærer undertitlen Anden omarbeidede Udgave, men er reelt en helt anden og næsten tre gange større bog (673 sider) end originalen fra 1808. Sent i bogens 196 sider lange "Indledning", inden den egentlige "Fremstilling" af mytologien begynder, indplacerer Grundtvig omsider Saxo som "vor gamle Classiker", der var en ganske anden mand end "hans Udgivere og radbrækkende Lov-Talere" (US V, 468). Nornen, altså skæbnen, har således spillet den sorte skole (klassiciteten) et mesterligt "Krigs-Puds", idet beundringen af Saxos latin hos Chr. Pedersen, Erasmus af Rotterdam, Stephanius og Torfæus sikrede ham international interesse. Men det blev en "fortvivlet" [dvs. ulykkelig] sag for "Classiskheden", at den kom i "en saadan Gothes Magt", eftersom Saxo "istedenfor at lade sig beherske af den, vanhelligede og misbrugde den paa det Fordærveligste, til at udruste og opsminke Rigets uforsonlige Fjender og Avinds-Mænd" (468-469). Grundtvig fortsætter: "Man tænke kun, det er Spas, Tiden vil ligefuldt vise, det var baade Nornens, Saxos og mit ramme Alvor" (469): Saxo balsamerede "virkelig Nordens historiske Aand i Romersk Kløgt", så hans bog blev "en forunderlig Sammen-Sætning af Literaturens Himmerig og Helvede". Men uden et præg af "Classiskhedens Stempel” ville den ikke have virket på de lærde. Først Stephanius, Brynjólfur Sveinsson og Torfæus prøvede i det 17. århundrede at forstå Saxo ved hjælp af islandske kilder (som de dog alle skrev om på nylatin!). Grundtvigs Saxo-betagelse er åbenbart i 1832 et noget flimrende fænomen. ${ }^{44}$

43 Af de resterende fem er "Folke-Vandringen" (nr. 25) i 3. person, "Karl den Store" (nr. 28) tiltaler emnepersonen med "du" og "I", og "Engeland" (nr. 47) tiltaler kun staten med "du”, mens "Det Østerrigske Huus" (nr. 41) har både "man" og "du" og "Sverrig og Norge" (nr. 50) kun "man".

${ }^{44}$ Vil man have et positivt eksempel, foreslår Grundtvig læsning af Shakespeares Hamlet, "som ei kan tænkes til, uden Saxo, skiøndt den vist nok ikke er udsprun- 
Efter denne erklæring indrømmer Grundtvig ligefrem, at når han aldrig har skrevet en Danmarkshistorie, skyldes det, at han stod tøvende over for oldsagnene, som han ikke "nænde at udelade, ikke maatte forkvakle, og ei vidste at behandle" (470). Saxos egen fortjeneste og uvurderlige værdi ligger imidlertid netop i disse sagn, han som "Critisk Historieskriver" (498) med sin "Romerske Pen, som et villigt Redskab, har bevaret fra fuldstændig Undergang" i sine første otte bøger. Altså er Saxo blevet "Nordens Minos, er Dommeren i de Dødes Rige, med Fuld-Magt af Nordens Aand til at anvise alle vore Critiske Historie-Skrivere deres Plads i Elysium eller i Tartarus, i Valhald eller i Helhjem: i en taknemmelig Ihukommelse, eller i en foragtelig Glemsel”. Ligesom Saxo bør nutidens historikere ærbødigt respektere "Folkenes poetiske Old-Sagn, som troe og mærkværdige [dvs. bemærkelsesværdige], for Videnskabeligheden saavelsom for Konst-Poesien uundværlige, Billeder af deres Barne-Drømme og Ungkarls-Dage”. Tilmed har Saxo haft "en beundringsværdig Takt til at adskille Poetiske Old-Sagn fra Ammestu-Snak, og ordne dem efter deres Indhold”, hvortil kommer en hos grammatikere "vel mageløs Skjalde-Aare". I hans fem første bøger samles alle gudesagnene, i de næste tre alle heltesagnene, så "vi har ondt ved endnu at giøre det bedre" (499). ${ }^{45}$ For resten daterer Grundtvig Saxos skrivervirke til perioden 1190-1220 (501, fodnoten). ${ }^{46}$

Grundtvigs Haandbog i Verdens-Historien, I, 1833, fastslår i kapitlet om folkevandringerne og Norden, at Nordtyskland og Danmark er sædet for definitionen af begrebet Menneske og arbejder som de eneste steder ud fra "vor Natur" og "Forsynets Plan" ved "tilsvarende Evner og Anlag" på en "organisk sammenhængende Verdens-Historie", hvor andre historikere, selv de nationaleste, "nøies med det atomistisk Sammendyngede" (US VI, 586). Han fremhæver, at trods tvivl om Saxos, Snorres og sagaernes "historiske Tilforladelighed i det Enkelte" (587) er alene deres eksistens

get af nogen Bog, men af Nordens Aand' (US V, 469). Englænderne har efter Grundtvigs erfaringer altid næret en forkærlighed for danskere, hvad der "folkepsychologisk og universal-historisk” betragtet er værd at huske på.

${ }^{45}$ Her hylder Grundtvig P.E. Müller som "Saxos bedste Ven iblandt vore Lærde" (499) med en fodnote om, at han uden sammenligning har vist mere forstand og rimelighed end sine kritiske forgængere "alle tilhobe".

${ }^{46}$ Nordens Mythologi, 1832, har naturligt nok et halvt hundrede henvisninger til Saxo og Vedels danske oversættelse af ham, hvoraf en del dog står dobbelt på en side, både i brødtekst og $\mathrm{i}$ en fodnote. 
vidnesbyrd om en "mageløs Historisk Retning" i Nordens middelalder. Denne anskuelse er "ældgammel”, og det beviser "Sagnenes Ægthed”, så "Mythe-Smedningen" kan som tegn herpå dateres til før Kristi fødsel. Ægtheden af "den Nordiske Mythe-Krands" som "Udtryk for Nordens Aand" bevises "paa det Gyldigste" ved "den Yndest, de nye Skjalde i Norden har fattet for den, thi i dem har Aanden vedkiendt sig den". Disse må være Ewald, Oehlenschläger og Grundtvig selv, og beviset er velment, men forekommer arbitrært. Nogle sider senere nægter Grundtvig bevidst at drøfte oldsagnenes efterretninger om en asiatisk indvandring i Skandinavien og en "Gude-Spilop i Sverrig" (596) ved en Odin, fordi dette blot er "løse Giætninger" uden værdi. Kritikken rammer Snorres fortale til den prosaiske Edda og de første kapitler af Ynglingesaga i Heimskringla. Saxo betragter rent ud denne Odin-figur som en bedrager (Liber I, 7.1).

Haandbog $i$ Verdens-Historien, II, 1836, forsvarer i kapitlet "Danskere og Nordmænd" Saxo med det "underlig sammensatte, dobbelte Binavn 'Grammatikeren og Poeten'” (US VII, 48) ${ }^{47}$ for hans otte bøger store "Vognmands-Læs af Nordiske Old-Sagn". ${ }^{48}$ Saxo mente i det at kunne finde "en vel noget fabelagtig, men dog i det Hele forsvarlig FædrenelandsHistorie", så "en langt større Skat end Knud Lavards" uden denne vurdering var "sunket til Havsens Bund, istedenfor at den nu paa halv-classisk Grund lod sig opgrave som Dannefa" (48-49). ${ }^{49}$ Saxo blev danskernes "Romerske Skribent fra det Tolvte Aarhundrede" (90). Grundtvig udnævner endvidere Saxos slutning på hele Gesta Danorum, hvor Danmark har fået "Lehns-Høihed" over Pommern og Rygen og besejret den tyske kejser ved Elben, til den "selv blandt de Lærde berømte, Latinske, hardtad Klassi-

47 Dette "Binavn" er lidt sært, for mens de vante ord om Saxo er Grammaticus, Scriptor eller Historicus (Stephanius 1645, Prologomena, 32-35), betegnes han i senere omtaler ikke som Poeta - et ord, han heller ikke selv nogensinde bruger (Friis-Jensen 1987, 24-25).

48 Grundtvigs ord "Vognmands-Læs" ligner et indirekte citat af ordet "plaustralis" oversat fra Ole Worms latinske brev til Stephanius 5. december 1642, trykt i Olai Wormii et ad eum doctorum virorum epistole, 1751, I, 243 (nr. 247); Grundtvig har ejet denne bog (Auktionskatalog 1873, nr. 2971). Worm-stedet handler dog om den latinske verdenskrønike Rudimentum novitiorum trykt i Lübeck 1475 og ikke om Saxo.

49 Hentydningen til Knud Lavards tabte skat går på en underordnet episode $\mathrm{i}$ Storebælt hos Saxo (Liber XIII, 3.1). 
ske Historie" om det gamle Danmark som "Nordens Dronning" (446)..$^{50}$ Derpå går det hastigt "ned ad Bakke" (447).

Grundtvigs skoleskrifter med kamp for det danske sprog og især dets mundtlige brug i pædagogiske sammenhænge lader sig ikke så godt forene med en programmatisk dyrkelse af netop Saxo. Det Danske Fiir-Klover eller Danskheden partisk betragtet, 1836, fremhæver dog Saxos praktiske eksempler på den danske uskrevne, men praktiserede "Arilds-Lov" om en forening af kongens eneherredømme og folkets ytringsfrihed (Bugge 1968, II, 14). Efter Saxos udmærkede latin må Grundtvig desværre konstatere modersmålets 600-årige trældom under "den forbistrede Latinske Grammatik og de forgiftige Romerske Classiker" (37). I næste kampskrift, Skolen for Livet og Academiet i Soer, 1838, indrømmer Grundtvig, at han trods sin "gruelige" forkærlighed for dansk og sit endnu "grueligere" had til latinen har vist mere flid og tålmodighed som Saxo-oversætter end de fleste latinbeundrere (115). Det var ud fra den tankegang, at "Fienden er farligere, jo mindre vi kiende til ham", men vi bør "lee ret hjertelig ad det blinde Had, der Intet vil lære af sine Fiender, skiøndt det er den eneste baade Nytte og Fornøielse, Man har af dem”. Samtidig anbefaler han, at vore bønder holder sig til "den Danske Saxo", altså Grundtvigs nye oversættelse. Ret fordel af en latinkundskab har man først, når ingen træller for den, men "nogle Faa ad Gangen beherske den og nøde den til at tralle for os". Dette ønske skulle gå i opfyldelse med fremtidige skole- og uddannelsesreformer.

I efteråret 1842 kom Grundtvig med en danmarkshistorie for børn på 64 sider, Mundsmag af Danmarks Krønike til Levende Skolebrug (optr. 1844, 1863, 1869 og 1877). Den indeholder fire siders versprøver fra Grundtvigs Saxo. Han mener i øvrigt nu, at Saxo har gjort danskerne til det rigeste folk, når det gælder om at fremkalde genlyd fra børn ved en historiefortælling. ${ }^{51}$

2. udgave af Krønike-Riim udkom 2. november 1842 med undertitlen ændret til Levende Skolebrug. Hele det indledende rids på prosa og syv enkeltdigte fra originaltrykket 1829 er udeladt, men 42 nyskrevne digte tilsættes. "Saxo Grammatiker” (på 22 4-linjede strofer, Grundtvig 1875,

${ }^{50}$ I Nordens Mythologi, 1832, mente Grundtvig, at "denne smukke Hvilepunkt" var pålagt Sven Aggesen og Saxo af Absalon (US V, 501).

${ }^{51}$ Horstbøll 1999, 184. 
118-121) præsenterer denne i 3. person som en nu 600-årig mageløs latinskrivende historiker med ægte dansk stof fra "Skjoldungers Slægte-Bog" (str. 3). Grundtvigs opfølgende karakteristik er særdeles detaljeret. Dåb og kristendom og pavekult interesserede ikke Saxo (str. 7), men hedensk-danske konger som Dan, Rolf og Skjold gjorde det des mere (str. 8). Og Saxo priste ikke fromme nonner ("tamme Kloster-Duer"), men hellere smukke valkyrier og kvinder som Sigrid (den udsøgt blufærdige med sløret ${ }^{52}$ ) og Signe (Hagbards trofaste elskede) (begge i Liber VII). ${ }^{53}$ Thyra Danebod (Liber IX, 11.2-11.7) står dog som både ægte dansk og kristen (str. 11-12). Saxos litterære smag er ikke en "klassisk Kraft-Sentens" (str. 13). Ovid og Vergil sætter han i skyggen (str. 14), og gamle danske folkeviser opsamlet hos ulærde kællinger ${ }^{54}$ genklæder han i "Romer-Dragt" (str. 15), hvad der i lærdes øjne er "Barbari” (str. 16). Men rim (dvs. digtning) af lærdes skuffer er værdiløse ("Persille-Værk", str. 17), og dem kan ægte danskere sprænge lige så let som Uffe hin Spage, da han prøvede brynjer for at væbne sig til den dobbelte tvekamp mod sakserne (jf. Liber IV, 4.6). I fast tonefald siger Grundtvig, at Saxo ville drille Romerriget ved netop ikke at vælge dets latinske guldalderstil, fordi han inderst inde "i det stille" bevægedes af sin “danske Drift” (str. 18), forkærligheden for det danske. Skønt Saxo benyttede latin, har han skrevet for "Danske under Ø” (str. 19), og hvis han har levet for dem, skal han også først dø, når de dør. Den dom står fast, så længe det danske sprog har sine digtere, og disse ser på Saxo med "Stor Ære paa det jævne” (str. 21), mens de modsat sparker til den veltalende klassisk-latinske historiker Livius. Derfor bindes Saxos navn til de danske heltes, og det uddør ikke, før disse glemmes (str. 22) - med et andet ord altså: aldrig.

Grundtvig vrider sig således ordentlig ved den latin, hvis kunstfærdighed han trods alt gerne vil have anerkendt som en stolt dansk dåd. Den

52 Sigrid blev en nudansk oldtidsheltinde efter P.F. Suhms succes med den nordiske fortælling Sigrid eller Kierlighed Tapperheds Belonning, 1772 (priskronet af Det smagende Selskab)(Lundgreen-Nielsen 1968, 8-15).

53 Et tidligere udkast til dette digt er offentliggjort af Svend Grundtvig, hvor hans fader tillader "Hegle-Hov'der" (ærkekværulanter) at kalde Saxos sagnpart for "Kælling-Snak" (1875, 290).

54 Det var Thomas Bartholins påstand, at "Kempe Viser" på dansk var sammenskrevet til gamle kvinder ved rokken, "ad colos aniles (...) compositæ" (1689, 543). 
kattepine var nok årsagen til, at han i 1 . udgave 1829 næsten ingenting havde om Saxo. I den forbedrede 1842-tekst indføjer Grundtvig en lang anmærkning om latin som romerrigets sprog, som kirkesprog og som "Skole-Sprog, dødt udledt af Romernes efterladte Skrifter" (Grundtvig 1875, 257-258), med fordærvelige resultater især i Tyskland og Norden og dèr igen især blandt præster, lovgivere og dommere. En anmærkning i 1829 med ros til Norges middelalderlige krønike ved Snorre "paa et levende Sprog” er slettet i 1842 (264). Først i 1842 får Saxo sin egen anmærkning som en sjællænder, en latinsk sprogkunstner (grammatiker) og en poet, der sansede den værdi i de gamle danske folkesagn, "som alle de andre Latinere kimsede ad", hvad der var "et stort Vidunder" (274) - om end han hellere skulle have givet dem "paa Modersmaalet, end latiniseret dem”. Snorre får i 1842 en ny anmærkning som den "berømte” samler af kongesagaer og eddatekster, hvis død i 1241 "i alle Maader" markerer "Grænsen for Middelalderens nordiske Storværk” (276). Det er en afkølende nekrologkarakteristik. En ultrakort anmærkning kommer også ind om Hrodgar som Saxos kong Ro (252), altså Roar. Under to forskellige længere notetekster 1829 og 1842 redegør Grundtvig endelig for Sveriges meget sene oldhistorieskrivning. Den vurderer han i 1842 som "ingen Ting mod Saxo og Snorre" (278).

Brage-Snak om Graske og Nordiske Myther og Oldsagn for Damer og Herrer, medio september 1844, består af 25 sammenlignende foredrag, holdt offentligt af Grundtvig på Borchs Kollegium i Store Kannikestræde fra november 1843 til og med januar 1844. Saxos navn forekommer i alt 14 gange. Præsentationen af ham i det 21. foredrag er for lægfolk: han har skrevet "en magelos Danmarks-Historie" (US VIII, 732) indeholdende "Nordens ældste og deiligste Sagn", hvor det om Hading især er "en dyrebar Levning fra den Danske Guldalder" (741). Men Grundtvig har også mindet om, at hvis vi ikke kendte Snorres Edda, ville "den bedste Deel af Saxos Værk” være os som “en 'lukket Bog”". Grundtvigs tale på det nationalliberale Skamlingsbanke-folkemøde 4. juli 1844 ligger i forlængelse af Brage-Snak. ${ }^{55}$ Her udlægges to hovedfigurer fra Saxo (uden kildeangivelse) folkepsykologisk: den fåmælte, sent vakte, men tapre og sejrende Uffe hin

55 Den trykte version Skov-Hornets Klang mellem Skamlings-Bankerne (udg. ca. 13. juli) fylder kun 12 sider i oktav (US IX, 29-36), men talen varede ifølge vidneudsagn ca. 11/4 time. 
Spage og den ordholdende slesvigske helt Folke (US IX, 31-32 og 35-36, jf. Liber IV, 4.1-4.11 og 3.5-3.6). Talen og mødet blev samtidig den konkret udløsende faktor til, at den allerførste folkehøjskole til virkeliggørelse af Grundtvigs idéskitser kunne åbne i Rødding 7. november samme år.

Grundtvigs sidste håndbog i myter blev det aldrig optrykte bestillingsarbejde Grask og Nordisk Mythologi for Ungdommen, udsendt lige før jul 1846 med trykkeåret 1847. Det omtaler i den summariske fortale ikke Saxo og bygger i den oldnordiske halvdel næsten udelukkende på islandske kilder, suppleret spinkelt med angelsaksiske. Ved sagnet om Hading nævnes Saxo lige, men hans version "giør os ikke klogere paa den rette Sammenhæng” (207), lader Grundtvig skolebørnene vide. ${ }^{56}$ Mens andre historiske kilder ultrakort defineres som f.eks. gotiske eller angelsaksiske, er der ingen nærmere bestemmelse af Saxo. Grundtvigs håndfaste verdenshistoriske udlægninger af nordiske myter, endda med stigende vægt på almen psykologi, kunne heller ikke få stort ud af Saxos spredte partier om hjemlige guder.

Lykønskning til Danmark med Det Danske Dummerhoved og Den Danske Høiskole, 1847, skulle egentlig fejre, at Grundtvigs Sorø-tanke i modereret form havde fået Christian VIII's godkendelse. Saxos 600-årige krønike indeholdt de danske stamfædres eftermæle, skrevet "ud af Folkemunde" (Bugge 1968, II, 246), hvad han selv hjemler i sin fortale, og hvad vi som læsere let føler, men just derfor var det "en stor Ulykke og Bedrøvelse, at den gamle Strøm holdt op at flyde”, så de olddanske tekster aldrig blev nedskrevet. Grundtvigs ungdomsprojekt med at oversætte Saxo tilbage til et "nogenlunde" folkeligt dansk fik ikke den heldige modtagelse og udbredelse, han havde håbet på, men nu søger han ny vej for en oplivet naturligt flydende "Eftermalets Strøm" i den kommende folkehøjskoles mundtlighed. ${ }^{57}$ Han indrømmer i sin fortsatte tekst, at de danske oldsagn hos Saxo

56 Saxo er derudover med i henvisninger på siderne 214 (Freja), 222 (Udgårdsloke), 242 (Hading), 248 (Skjold), 248 og 251 (Frode Fredegod), 253 (Roe eller Roar), 254 (Rolf Krage og Bjarkemålet), 257 (Hamlet), 265 (Jarmerik), 267-269 (Stærkodder), 269-270 (Bråvalla-slaget) og 273 (Thorkild Adelfar); desuden refereres s. 254-256 Saxos Balder-sagn (Liber III, 1.1-3.7), men sært nok uden oplyst proveniens.

57 Grundtvigs tanke før Christian VIII's død og Treårskrigens udbrud i 1848 gjaldt en central institution for danskhed i Sorø som national modvægt til det latinske Københavns Universitet. 
fra kong Dan til Stærkodders død (Liber I-VIII) ikke er historieskrivning, men brudstykker af "ældgamle historisk-poetiske Viser og Kveder" (248). At dyrke dette stof er så meget vigtigere, som det overskygges af først latin-, så tysk-begejstring lige fra Valdemar den Stores død (1182) indtil nutidens stænderforfatning (1831 og 1834) og den forestående oprettelse af højskolen i Sorø. Til slut i den lille bog trøster Grundtvig sig med, at det meget lange tidsspand i Saxos historie ${ }^{58}$ fordunkler de seks beklageligt dystre århundreder, som det menige danske folk måtte gennemleve fra 1241 (Valdemar Sejrs død) til 1839 (Christian VIII's tiltræden).

Grundtvigs nye tidsskrift Danskeren, et Ugeblad, I-IV, 1848-1851, er et resultat af to sammenfaldende begivenheder, treårskrigen i og om SlesvigHolsten 1848-1850 og den nye grundlov og rigsdag fra 1849. Her påberåber ikke engang Grundtvig sig Saxo særlig tit. ${ }^{59}$

Et par krønikerim i Danskeren, II, 1849, behandler Saxo-udgiveren Chr. Pedersen og oversætteren Vedel. Grundtvig opfatter Saxos latin på tryk som en hæmmende "Kolden" (US IX, 211), altså koldfeber (en art malaria). Vedel brød i sin danske oversættelse denne grønlandske "IisbjergMur" (212), så f.eks. to "Iistapper" som Frode og Svanhvide kom til Danmark og fik liv og sang (jf. Liber II, 2.1-2.10).

I Danskeren, III, 1850, gør Grundtvig på prosa nar ad udenlandsrejser og udenadslære, bl.a. ved at inddrage Saxos (og efter ham Rimkrønikens) beretninger om en ældre kong Gorms interesse for at samle sig kundskab om verdens nordligste ende, assisteret af ekspeditionslederen Thorkild Adelfar (1850, 147-150, VUV, 356-365, jf. Liber VIII, 14.1-15.13). Nogle hæfter senere følger et afslappet causeri om Saxos Signe og Habor (385-400, Liber VII, 7.2-7.17). Det er en af Saxos mange "baade gode og gamle" fortællinger (385), som dog er "mere mythisk end historisk, altsaa paa Dansk mere indvendig end udvendig" (386). Derfor er det Signes hjerte og ikke rester af hendes jomfrubur, forskerne skal lede efter. Imidlertid koncentrerer Grundtvig sig mere om tre optrædende rådgivere, vel ud fra sine egne erfaringer som medlem af Den Grundlovgivende Rigsforsamling 18481849 og af Folketinget 1849 ff. Han håber, at hans læsere og især læserinderne heraf kan erfare, at "vore gamle Myther og Frasagn" (387) ikke alene

58 Saxo siger ligeud, at Kristi fødsel fandt sted under Frode Fredegods regeringstid (Liber V, 15.3).

59 I det allerførste nummer mindes han dog med "gamle Saxo" det givtige sildefiskeri i Øresund (1848, 5, efter Saxos Præfatio 2.4). 
er fornøjelige at tilegne sig, men at de udgør "en Skat af indfødte Grundtanker", der er "let at bære" og "til uberegnelig Nytte i det daglige Liv", så man ikke af lygtemænd (falske rådgivere) lokkes ud i moser til manden med røde strømper eller op til månemanden for et kålhoveds skyld. ${ }^{60}$ Grundtvig pointerer, at det ikke drejer sig om, hvad de gamle tænkte på med fortællingerne, men om, hvorledes de kan bruges hos os. Hidtil er sagn og myter blevet behandlet ligesom guldringe fundet i gravhøje, altså som "gamle Sieldenheder" (388) samlet og fremlagt på "Rundetaarn" (i den i 1819 åbnede oldsagsudstilling for "Nysgierrige" på biblioteksetagen over Trinitatis Kirkeskib). Til Saxos to politikere, den retsindige Bilvis og den ondskabsfulde Bolvis, ${ }^{61}$ føjer Grundtvig en tredje selvskabt, Blækvis. Med al visdom hentet fra "Blak og Bogtrykker-Sværte" (394) er denne en bedrøvelig lærdommens "Don Quixote” (395), kun mindre morsom end den verdensberømte romanfigur. Indlægget løber herfra ud i en aktualisering af situationen i Danmarks tredje krigssommer, en uge før 1-årsdagen for 6. juli-sejren ved Fredericia.

Den blodige danske sejr ved Isted 25. juli 1850 fejrede Grundtvig blandt andet med en hyldestsang til den slesvigske jomfru Hæthe, Saxos Hetha, en deltager i Bråvalla-slaget (499-502, PS VII, 292-294, Liber VIII, 2.4, 2.6, 4.3 og 5.2). Han kalder hende også jomfru Gloriant, den kvindelige hovedperson i folkevisen Holger Danske og Burmand (DgF 30D, hvis stof ikke er med i Saxo). Navnene på de to heltinder forklares i en Grundtvigfodnote: begge betyder 'hæder'.

I den poetologiske tankedigtning "Skjaldelivet i Danmark", Danskeren, IV, 1851, henviser Grundtvig til Saxos sagn om "Sigrid den Bly" (240, PS VII, 403, Liber VII, 4.1-4.8), som han desuden gendigter i en ballade (uden kildeangivelse, 289-295, PS VII, 427-431). Besværet med at få ellers ud mærkede dannekvinder til at "slaae Øinene op" (320, jf. 310) behandles i prosa-bidraget "Dansk Oplysning. II" i Sigrids navn. Saxos Hading-sagn (fra Liber I) bruges endelig i digtet "De danske og de tyske Alfer" til at skelne mellem disse nationalkarakterer (335, PS VII, 433-438).

${ }^{60}$ Gamle dialektudtryk henholdsvis for en stork med røde ben og for mandsansigtet i månen, som en borger, der blev beskyldt for at have stjålet et kålhoved, ønskede sig op til, såfremt han var skyldig (jf. et ordsprog hos Peder Syv 1688, 252). 61 Begge er med i Suhms populære fortælling Signe og Habor eller Kierlighed sterkere end Døden, 1777. 
Tæt på ugeskriftets planlagte ophør skriver Grundtvig 8. november 1851 i prosastykket "Danmarks Fare og Danmarks Frelse" blandt andet om et søslag hos Saxo, hvor nogle feje jyder for at frelse deres liv sprang over bord "i rum Sø" (705) og druknede. Deres usle optræden kommenterer Saxo grundigt med moraler (Liber XI, 4.1). ${ }^{62}$ Lige efter mindes Grundtvig Saxos Vermund-Uffe-sagn "fra Arildstid” (708, Liber IV, 4.1-4.11).

Alt i alt giver de fire tykke bind Danskeren således eksempler på en nutidig brug af Saxos sagn, som dog er langt fra at overtrumfe de norrøne kilder i Grundtvigs bevidsthed. ${ }^{63}$

\section{Udklang}

I 1854 holder Grundtvig fra februar til april 12 onsdagsforedrag om $H ø i-$ nordens Historie for Den Danske Forening (Fasc. 368, 11 utrykte, det sidste trykt). ${ }^{64}$ Lukas Engelskmand, der ifølge Saxo skal have underholdt modfaldne danskere under et Absalon-togt mod venderne (Liber XIV, 40.9), er emnet for hans to første taler, med det fromme ønske, at englændere og nordboer må være tilstrækkeligt beslægtede til at kunne opmuntre hinanden i en snæver vending. Denne perifere statist hos Saxo gjorde Grundtvig ikke mere ud af.

I 1855 har Grundtvig og hans voksende tilhængerskare uden for hovedstaden medvind i form af en vækst i folkehøjskolernes antal. Ved 2. udgaven fra juli 1854 til august 1855 af sine tre oversatte bind Saxo omdøber Grundtvig på titelbladet historikeren fra Grammaticus til "Runemester", hvad der udlægges i et nyt indledningsdigt om hædersnavnet Danmarks

62 Saxos ræsonnering er så bred, at Vedel i sin oversættelse afkorter den betydeligt (1575, C[C]XXXVIII). Grundtvigs egen oversættelse medtager dog passagen komplet. Det er for resten lidt overdrevent med den rumme sø, for søslaget fandt sted ud for Djursland i mundingen af Grenåen (som Saxo kalder "fluvius" og "flumen").

63 Brug eller omtale af Saxo i Grundtvigs folketingstaler i 1850'erne (der alle er trykt i Rigsdagstidende efter stenografisk nedskrift) er ikke undersøgt.

${ }^{64}$ Den danske Forening stiftedes efter forberedende møder den 3. maj 1853 med Grundtvig som formand og eksisterede, om end stærkt svækket, til og med 1856 (Lundgreen-Nielsen 1992, 130-139). 
"Guldalders Runerister" (str. 5, US IV, 197) med bestemt kassation af hans “latinske Øgenavn” (str. 9, 198). Stridbar er især strofe 13:

Saxe Dansker! gamle Ven,

Dansk selv i Latinens Lænker!

Runemester er kun den,

Der kan skrive, som han tænker,

Der kan tænke frit og fort,

Der kan tegne Lys og Skygger,

Der kan tegne Hvidt og Sort,

Tegne alt, hvad Ord udtrykker!

(198)

Selv tyskerne har ikke på kejser Barbarossas tid (2. halvdel af 1100-tallet) en tilsvarende digter, der endog " $i$ romersk Bast og Baand" (str. 14, 199) er kyndig på nordiske runer. ${ }^{65}$

I et efterfølgende ligeledes nyt forord, dateret 1 . juli 1855, meddeler Grundtvig, at han har sammenholdt hele sin oversættelse med grundteksten, og det er vel i den anledning, han har generindret den engelske Lukas. For resten finder han sin danske Saxo dels "laselig" (US IV, 201) i fortællestil, dels i gengivelsen af Saxos egne ræsonnementer "i det mindste meget tydeligere og fuldstændigere paa Dansk end nogensinde før".

Saxo kan ikke indpasses i Grundtvigs kirkehistoriske profeti Christenhedens Syvstjerne. Et Kirkeligt Sagakvad i 1860 (i alt 696 strofer à 7 verslinjer). I afsnittet "Den Nordiske Menighed" (først separat trykt i Dansk Kirketidende 1855) får Hading-sagnet og Torkild Adelfar hver én strofe uden proveniensangivelse (1860, 163 og 188).

I 1860'erne skrev Grundtvig fire fuldstændige digtninge, alle autodaterede, men gav dem uden nogen begrundelse ikke i trykken, skønt han

65 Saxo har nogle henvisninger til runeindskrifter og runebrug, men runologi står reelt spagfærdigt i hans kildemateriale. "Runemester" betyder efter islandsk rúnameistari snarere en, der er kyndig i runekunst, ikke blot til nedskrivning, men også til at udøve trolddom med. At Stephanius (1645) i sine Saxo-kommentarer trykker en del hidtil ukendte islandske oldtidstekster med runer, er aldeles uhistorisk, hvad hans islandske korrespondenter sagde ham rent ud. Forbilledet var Ole Worms bog om runekalendere Fasti Danici 1626 og dennes senere skrifter om runer. 
gerne lånte håndskrifter med dem ud til sine tilhængere og ikke forbød afskrivning. Af dem blev Dansk Ravne-Galder fra 1860 trykt af Holger Begtrup i 1909 (US X, 364-489) og optrykt i 1929 (PS VIII, 315-467). Saxos navn forekommer ikke her, men enkelte af hans personer er med. ${ }^{66}$

De andre tre digtninge offentliggjordes første gang i det stærkt forsinkede bind IX af Grundtvigs Poetiske Skrifter i 1930. Den ældste hedder Nordens Myther, 18 digte skrevet 1864, rækkende fra asernes tilblivelse til Ragnarok. I digtet "Slejpner” repeterer Grundtvig Hadings ridetur på Odins hest, der opfattes som symbol på god og åndsbærende digtning (PS IX, 218, 219, 225). I sin ungdoms asabegejstring mente han at kunne ride ligesom Hading og nå sit givne mål:

Men at det kun var en Drøm,

Har jeg nu opdaget,

Thi skjønt jeg med Tidens Strøm

Nok har mig umaget,

Jeg den i det danske Rom

Dog slet ikke overkom:

Dampen var ej oppe.

(PS IX, 225)

"Rom" må være Saxos latin, og i en del af digtet repræsenterer asa-ridehesten "Guldtop" eller "Guldmanke" (fra eddakvadet Grimnismál, str. 30) den alt for letløbende falske digtning, der fatalt leder til "Skin” og "Blændværk" (PS IX, 224). Grundtvig afstår imidlertid fra at fælde dom over sin ungdoms versdigtning, hvor han "næsten" red gennem alle nordiske versmål "saa glat som nogen Aal" (221). I digtet "Mimer" om visdomsbrønden ser Grundtvig ejermanden som et billede på krønikegenren, fordi han som halvt as, halvt jætte stolede på sund fornuft, opsamlet erfaring og fastholdt kronologi. Den konkrete afskæring af hans hoved (fra kapitel 4 i Snorres Ynglingasaga i Heimskringla) blev en metafor i åndshistorien for Saxos forfatterskab på "det klassiske Latin" (229), og i "Bogorme-Gaarden" (bogbranchen) ses endnu Mimers "Jordelin" (de latinske Saxo-tryk). Hans balsamerede hoved endte på Island, for "Højnordens Sagastil / Med

${ }^{66}$ Hading (US X, 365-367, 436, 458), Hjarne (406, 436), Amlet $(436,442)$ og Signe $(424,446)$. 
sin Mumlen og sit Smil / Er dog Dødmands Tale” (230), der vel kan udforskes af de lærde, men ikke duer til at afmale andet end jordisk liv. Saxos navn gentages som signatur (230 og 231) i digtet "Hadding", hvor det indleder en bred gengivelse af rideturen over havets bølger og kvinden ved den låste port til evigheden (232-235). Men langtfra ukritisk. Saxos sprog, mener Grundtvig, er rækker af trylletegn, "Alf-Runer" (230), der ikke er til at blive klog på, skønt dette sagn "ret fortalt" ville have glædet "Øren mange". Løsningen på hanegalet fra fuglens afhuggede hoved bag den høje og tætte mur var imidlertid ikke til stede i Danmark på Haddings tid: Kristi opstandelse fra de døde. Det følgende digt "Gejrodsgaard” bygger på Thors besøg hos en jætte (fra Bragarœður i Snorres Edda), af Grundtvig frit udlagt som en satire over forkasteligt tysk åndsliv i det 19. århundrede. Det kombinerer han med Saxos beretning om Thorkild Adelfars første ekspedition til det højeste Norden (Liber VIII, 14.1-14.20). Enhver højtysk skolemester er for Grundtvig en "Dødbider" (239), og det hele syn har "Saxo Runemester" med "Danskens Blik paa Sagen" (240) fremkaldt. Nogle jætter (der er Grundtvigs opfindelse) danser en menuet af 'ja' og 'nej', og det røber ham "Spor af Ving-Thors Asakraft" hos tyskernes "Luftens Kejser" Hegel, mens rollen som Snorres sammensvorne jætte-søsterpar "Greip” og “Gjalp” (241) går til Kant og Schelling. ${ }^{67}$ Den sidste filosofs efternavn rimer endda fint på ordene om, at de hver for sig ender som en "skrutrygget Jættekælling". ${ }^{68}$ Fra samme år haves endelig et utrykt enkeltdigt "Sigrid" (PS IX, 274-276), der endnu eng ang omhandler Saxos sky kongedatter fra Liber VII. I sin slutstrofe skriver Grundtvig, at det "danske Folkehjærte" har gjort denne vise om sig selv, så Saxo signerer den ikke.

${ }^{67}$ Hos Snorre dræber Thor kort og godt den lumske jætte Gejrod med et glødende stykke jern og hans to døtre Greip og Gjalp ved at sidde på dem og således brække deres ryg (Resen 1665, fabel 57). Hos Saxo møder den snedige Thorkild og hans ret passive kong Gorm kun Gejrods broder Guthmundus (Gudmund), men besigtiger dog gerningsstedet med levningerne af hans dræbte slægtninge (Liber VIII, 14.6 og 14.15).

${ }^{68}$ Snorre lader i øvrigt datteren Gjalp have forsøgt at hindre Thors besøg ved skrævende over en elv at sende en kæmpemæssig urinstrøm mod ham, som han dog redder sig i land fra. Grundtvigs gendigtning nedtoner denne scene (PS IX, 237) og skynder sig at tolke oversvømmelsen som billede på de årlige tyske bogmesser (der siden 1764 var blevet afholdt samlet i universitetsbyen Leipzig) (238). 
Den næste digtning er fra 1866 og hedder Havamaal. Grundtvig belærer leksikalsk om fænomenet Ordet, dets historie, væsen og funktion på intet mindre end 6.114 verslinjer fordelt på 1.019 strofer. Kun i titel er det beslægtet med den ældre Eddas Hávamál. I det historiske afsnit er de kristne angelsaksere med Beda tilgodeset (PS IX, 392-393) og lidt senere også danskerne:

Næppe regnet mellem Præster,

Som et Særsyn holder Stik

Vist nok Saxe Runemester,

Pløjed rask sin Grammatik;

Strax man her dog ihukommer

Svalen, som gjør ingen Sommer.

$(397)^{69}$

At den hedenske Gorm den Gamle mistede sønnen Knud Dane-Ast, fik Saxo dog berettet (418; jf. Liber IX, 11.5-11.7). Hading-sagnet gør Grundtvig atter en rundgang om (432-433).

Overraskende og uden nogen klar markering skifter Grundtvig fra sin egen tale (om "vi" og "os") til at blive tiltalt med et "du" af en uidentificeret leende person betegnet som "Verden"; det er måske en afspaltning af ham selv, altså en indre dialog fra og med strofe 783 (PS IX, 451 nederst). Han angribes for at tro, at tyskheds lænker kan bringes til at briste for "Sang og Kvindelist" (456). For at redde alle "danske Minder" fra "Glemsels-Havet" begravede Saxo dem i "en Hule-Vraa", hvorfra de kunne genvindes som "Dannefæ", i hvert fald "nogenlunde" (457). Saxo er jo virkelig et "sært Vidunder / Hemmelig til Veje bragt, / Som af Vaner og af Aser / Sammenflydt var gamle Kvaser". Billedet er hentet fra Snorres Edda (Resen 1665, fabel 60), hvor denne af aser og vaner skabte person blev dræbt af to dværge, der forklarede, at han blevet sprængt indefra af sin overvældende store visdom, hvorefter de omgjorde hans dødelige rester til skjaldemjød. Her i Grundtvigs digt indvender den anonyme protestrøst (i "I"-form), at hele Saxos bind er latinsk og dets indhold næppe "folkeligt", så at det blev et mesterstykke, er bare tilfældigt (en "Slumpelykke"). Videre angri-

69 At Saxo holdt stik, betyder, at han var hævet over kritik for sit niveau som skribent og var anerkendt af sine læsere (f.eks. Erasmus af Rotterdam). 
bes Grundtvig af "Verden” for sin fordanskning af Saxo på "Lavlandets Folkesprog" (458), som forvansker den nordiske arv til lokalt sjællandsk og slutter med en forelskelse i "Pære-Danskeriet". Hudfletningen forsætter og fylder her i alt 39 strofer, inden jeget forsvarer sig med et indlæg, der inkluderer også Beowulfskvadet (467-469). Angriberrøsten fortsætter i "du”-form med, at Saxo, der selv kendte sagnene på "Islandsk", med vilje omskrev dem til Vestas præster og ikke til Sagas yndere (474). ${ }^{70}$ Siden Saxo har Danmark ikke fostret "en Vidskabsmand" (475), som bekendte sig til det danske, og Holsten og Norge kaldes endnu gerne "Kronens Ædelsten” i stedet for Danmark. Løsningen viser sig adskillige strofer senere at ligge i en opblomstring af den danske kvindelighed, der føder et livsdueligt barn. ${ }^{71}$

Den sidste af de fire digtninge, Højnordens Rimkrønike. Hundedagene 1867, er en kortere digtkreds, der hviler på Saxo ved at fortælle om Danmarkshistorien fra kong Skjold over Hading, Vermund og Folke, Uffe hin Spage, Roe og Helge, Frode Fredegod, Ingel og Stærkodder, Sigrid og Ottar, Habor og Signe, Harald Hildetan, Gorm Vilderede, Torkel Adelfar og Tyra Dannebod samt kongerne fra Svend Tveskjæg til Valdemar den Store, dog tilsat enkelte norske middelalderkonger fra Heimskringla. På egen hånd fortsætter Grundtvig fra Valdemar Sejr til Frederik VII, ${ }^{72}$ idet de svenske monarker Gustav Vasa, Karl 12. og Karl Johan indflettes. Saxos navn henkastes under Frode Fredegod (PS IX, 520), og han præsenteres som den sjællandske "Danskens Penneforer" (543) under Knud den Store, men kommer ikke til syne under "Valdemar den Store", end ikke i strofen om Absalon (574). Saxos senere udgivere og oversættere er lige så usynlige i de digte, der dækker deres samtid. Den gammeldanske Rimkrønikes monologform er gennemført i 25 digte, mens 21 er i 3. person (og en i ubestemt).

Og i 1865 forberedte Grundtvig et større trøsteskrift til det nederlagslammede danske folk i det reducerede rige efter fredsslutningen i Wien

\footnotetext{
70 Vesta er arnens og ildens gudinde, en af de mest yndede i det gamle Rom.

71 Digtet formeligt skriger på realkommentarer og ville blive klarere ved en typografisk opsætning, der søgte at bestemme, hvem der taler hvornår på den meget lange strækning, det dækker.

72 Et selvstændigt nummereret monologdigt om Christian VII findes ikke, så han skildres kun som gået fra forstanden i str. 2 af digtet "Frederik den Sjette" (PS IX, 597).
} 
30. oktober 1864. Over for de triumferende tyskere ville han stille den slesvigske jomfru Hedd eller Hæde, på latin Hetha, fra Saxos beretning om Bråvalla-slaget (Liber VIII, 2.4 og 2.6, 4.3 og 5.2): hun bør nu sendes til Slesvig for at vogte Danmark og Norden mod tyskhedens indtrængen og fremgang (Fasc. 203). Det lykkedes dog ikke for Grundtvig at gøre hende til en folkelig kendt figur. ${ }^{73}$ I et andet håndskrift er det atter Saxos Sigrid med sløret, der står for den ægte danske kvindelighed i en forsvarsposition (Fasc. 204, fra Liber VII, 4.1-4.7). Men det bliver Freja og hendes tabte elskede Ottar fra islandske tekster, der efterhånden hos Grundtvig vinder førstepladsen som symbol på tab, længsel og genoprettelse. Hans sidestærke udkast smelter dog aldrig sammen til en færdig helhed og forbliver utrykt. ${ }^{74}$

\section{Epilog}

Grundtvig skulle være 26 år, før han alvorligt tog fat på at indplacere Saxo i sine behandlinger af Danmarkshistorien, og han var næsten 32 år, før han begyndte at oversætte ham fra grunden af, hvad han så sluttede som 40-årig. Sprogligt-stilistisk er Grundtvigs Saxo-oversættelse og de utrykte papirer omkring den pænt udforsket. Det er her blevet suppleret med de både historiske og nutidige vurderinger, Grundtvig anlagde på Saxo i sit lange liv.

Nogen magtfuld konklusion kan næppe drages af oversigten. Saxos aktiveste rolle i Grundtvigs liv var reelt udspillet i 1823, da det 3. og sidste bind afgik til subskribenterne i Danmark og Norge. Det kunne Grundtvig dengang ikke vide. Han strejfede imidlertid mange gange senere Saxos værk og det trods op- og nedture med en stigende anerkendelse. Grundtvig var veludrustet til at læse og forstå Saxos latin på egne vegne, men den var ikke noget godt redskab til at slås for folkelighed med, og de eksisterende danske oversættelser, Vedels på gammelmodigt krønikedansk, Schousbølles på en art Holbergsk prosa og Grundtvigs på arkaiserende

\footnotetext{
${ }^{73}$ Vedel forbinder uden belæg hos Saxo hendes navn med Hedeby (1575, CLXIX).

${ }^{74}$ Lundgreen-Nielsen 1992, 151-161.
} 
borgestuedansk, var nok for specielle og for tidsbundne til at behage et bredere publikum i det 19. århundrede med ændrede forudsætninger.

Grundtvigs taler ved indledningen eller afslutningen på undervisningsforløb (uden ham) ved hans egen folkehøjskole Marielyst 1856-1871, i alt 27 kortere tekster, betjener sig veloplagt og næsten lystigt af nordiske myter og sagn ved siden af bibelsteder, gammeldanske ordsprog og Rimkrøniken, men Saxo fremdrages ikke. Tværtom overses han tilsyneladende bevidst. Sagnet om den ældre kong Gorm og hans udforskning af Gejrodsgård (Liber VIII) betegnes 7. november 1865 som "et gammelt Dansk Æventyr" (Grundtvig 1956, 78), der er bedre at få forstand af, end tyskerne mener. 5. november 1867 minder Grundtvig om "den fjerne hartad glemte Fortid i Skjolds og Haddings, Frode-Fredegods og Rolf Krakes fjerne Dage” (93) i forbindelse med folkeånden, hvis liv igen er afhængig af "Modersmaalet”. Nok genfortælles 20. april 1869 fra Saxo meget kort sammenstødet mellem Stærkodder og den tysk-influerede kong Ingel (Ingjald)(Liber VI), hvorpå Grundtvig blot beretter, "at denne Begivenhed speiler sig tydelig i et gammelt nordisk Æventyr, som er lagt til Grund i den saakaldte Bjovulfs Drape" (100). Således hemmeligholder Grundtvig for eleverne, at Saxo er kilden til disse historier. Utvivlsomt trak de norsk-islandske kilder stærkere og hyppigere i Grundtvig, fordi de åndshistorisk, psykologisk og sprogligt lå tættere på den danskhed, som han i moden mandsalder gjorde til en væsentlig del af sin verdslige livsanskuelse og gav i arv til eftertiden.

\section{Forkortelser}

PS I-IX Svend Grundtvig og Georg Christensen (udg.) (1880-1930), N.F.S. Grundtvigs poetiske Skrifter, I-IX, København, Gyldendal.

US I-X Holger Begtrup (udg.) (1904-09), Nik. Fred. Sev. Grundtvigs Udvalgte Skrifter, I-X, København, Gyldendalske Boghandel - Nordisk Forlag.

VUI-X Christensen, Georg og Koch, Hal (udg.), Verker i Udvalg (19401949), I-X, København, Gyldendalske Boghandel - Nordisk Forlag. 


\title{
Flemming Lundgreen-Nielsen
}

\section{Litteratur}

\author{
Verker af Grundtvig
}

Fasciklerne 179, 203, 204, 230.4, 240, 241, 242, 267.1, 288.1-6, 368, 400.1, 401, 501.1, 520, 521, 544.

- (1807), "Et Par Ord i Anledning af det forkyndte Sørgespil: Signe" i Ny Minerva, juni 1807, 225-248.

- (1808a), Nordens Mytologi eller Udsigt over Eddalaren for dannede Mand der ei selv ere Mytologer, København, Andreas Seidelin.

- (1808b), Indbydelse til Gamle Nordens Venner, København, Andreas Seidelin.

- (1809), Optrin af Kampelivets Undergang i Nord, 2, København, J.H. Schubothe.

- (1810), Nytaarsnat eller Blik paa Kristendom og Historie, København, Andreas Seidelin.

- (1811a), Optrin af Norners og Asers Kamp, 1, København, J.H. Schubothe.

- (1811b), Saga. Nytaarsgave for 1812, København, Andreas Seidelin.

- (1812), Kort Begreb af Verdens Krønike i Sammenhang, København, Andreas Seidelin.

- (1813), Til Fadrenelandet om dets Tarv og Fare. Et Ord, København, H.P. Høeckes Enke.

- (1814a), Roskilde-Riim København, Andreas Seidelin.

- (1814b), Roskilde-Saga til Oplysning af Roskilde-Riim, København, Andreas Seidelin.

- (1815a), Kvadlinger eller Smaakvad, København, Andreas Seidelin.

- (1815b), Prøver af Snorros og Saxos Krøniker i en ny Oversattelse samt et Ord til Danske og Norske, København, Andreas Seidelin.

- (1815), Heimdall. Dansk Nyaars-Gave for 1816, København, Andreas Seidelin.

- (1817), "Fornioter" i Danne-Virke III, 190-200, København.

- (1818-1822), Danmarks Krønike af Saxo Grammaticus I-III, København, Bekostet af Krønikens Danske og Norske Venner. [Eget forlag]

- (1820), Bjowulfs Drape. Et Gothisk Helte-Digt fra forrige Aar-Tusinde af AngelSaxisk paa Danske Riim, København, Andreas Seidelin. 


\section{Grundtvigs vej til Saxo}

- (1824), Nyaars-Morgen [1824] (1901), ved Begtrup, Holger (udg.), København, Karl Schønbergs Forlag.

- (1832), Nordens Mythologi eller Sindbilled-Sprog, historisk-poetisk udviklet og oplyst, København, J.H. Schubothes Boghandel.

- (1833, 1836, 1843-1856), Haandbog i Verdens-Historien. Efter de bedste Kilder. Et Forsøg samt Tillag. Det attende og nittende Aarhundrede. (1715-1866) i 1869 med 2. udgave $(1867,1862,1869)$, København, Den Wahlske Boghandels Forlag, 2. udg. Karl Schønbergs Forlag.

- (1838), Nordiske Smaadigte, Christiania, Chr. Grøndahls Forlag.

- (1844), Skov-Hornets Klang mellem Skamlings-Bankerne, København, C.A. Reitzel.

- (1848-1851), Danskeren, et Ugeblad, I-IV, København, I i kommission hos F.H. Eibe, II-IV på eget forlag.

- (1855), Danmarks Krønike af Saxe Runemester. Anden Udgave, I-III, København, C.G. Iversen.

- (1860), Christenhedens Syvstjerne. Et Kirkeligt Sagakvad, København, Th. Michaelsen \& Tillges Forlag.

- (1882), Grundtvig og Ingemann. Brevvexling 1821-1859, ved Grundtvig, Svend (udg.), København, Samfundet til den danske Literaturs Fremme.

- (1956), Taler paa Marielyst Højskole 1856-71, ved Johansen, Steen (udg.), København, Gyldendal.

- (1979), N.F.S. Grundtvigs Dag- og Udtogsbøger, 1-2, ved Albeck, Gustav (udg.), København, C.A. Reitzel.

\section{Verker af andre forfattere}

Ahlefeldt-Laurvig, Frederik (1927-1931), Generalen, I-VI, København, Tryde.

Baden, G. L. (1809), Dr. G.L. Baden til Hr. Geheimekonferentseraad F. v. Moltke om vor danske Histories Fader Saxo Grammaticus og Trangen til en ny Udgave af ham, Odense, G.L. Badens Forlag.

- (1815), Dansk-Norsk Historisk Bibliothek, indeholdende Efterretning om de Skrifter, som bidrage til dansk-norsk Historiekundskab, Odense, Søren Hempel.

Bartholin, Thomas Thomæ Filius (1689), Antiqvitatum Danicarum de causis contempte a Danis adhuc gentilibus mortis libri tres ex vetustis codicibus \& monumentis hactenus ineditis congesti (1689), København, Joh. Phil. Bockenhoffer.

[Beowulf] (1815), De Danorum Rebus Gestis Secul. III \& IV. Poëma Danicum Dialecto Anglosaxonica, ved Thorkelin, Grím. Johnson (udg. og lat. overs.), København. 


\section{Flemming Lundgreen-Nielsen}

Bugge, Knud Eyvin (1965), Skolen for Livet. Studier over N.F.S. Grundtvigs padagogiske tanker, København, G.E.C. Gads Forlag.

- (1968), Grundtvigs skoleverden i tekster og udkast, I-II, København, Institut for dansk Kirkehistorie \& G.E.C. Gads Forlag.

Dam, Poul (1992), Grundtvig-tekster i sangbøgerne med sarligt henblik på højskolesangen. En bibliografisk oversigt, Århus, Aros.

Davidson, Hilda Ellis \& Fisher, Peter (1980), Saxo Grammaticus The History of the Danes. Book I-IX, vol. II Commentary, Suffolk \& New Jersey, D.S. Brewer \& Rowman and Littlefield.

Finnur Jónsson (1772-1778), Historia Ecclesiastica Islandia, I-IV, København, Gerhard Giese Salicath.

Fortegnelse over N.F.S. Grundtvigs Bibliothek, som bortsalges ved offentlig Auction (1873), København, E.C. Løsers Bog- og Nodetrykkeri.

Frederiksen, Emil (1948), Den unge Grundtvig og andre Essays, København, Det Schønbergske Forlag.

Friis-Jensen, Karsten (1987), Saxo Grammaticus as Latin Poet. Studies in the Verse Passages of the Gesta Danorum, Rom, L'Erma di Bretschneider.

Fundinn Noregr, Halfs Saga, Fridthofs Saga og Sögubrott om nogle gamle Konger i Danmark og Sverige (1824), ved Rafn, Carl Christian (overs. og komm.), København, Forfatterens forlag.

Galster, Kjeld (1922), Ingemanns historiske Romaner og Digte, København, H. Aschehoug \& Co.

Goethe, Johann Wolfgang (1967), Werke, IX, ved Trunz, Erich (udg.), Hamburg, Christian Wegner Verlag.

Holberg, Ludvig (1974), Ludvig Holberg Latinske Smaaskrifter ved Kragelund, A. (udg. og overs.), I-II, København, G.E.C. Gad.

Holberg, Ludvig (1731), Solutio problematis de hypothesibus historic Danice, optr. 1974 med dansk overs. og noter ved Kragelund, A., I, 286-323, II, 123-133, København, G.E.C. Gads Forlag.

Horstbøll, Henrik (1999), Menigmands medie. Det folkelige bogtryk i Danmark 1500-1840. En kulturhistorisk undersøgelse, København, Det Kongelige Bibliotek og Museum Tusculanums Forlag.

Ingemann, B.S. (1824), Waldemar den Store og hans Mand. Et episk Digt, København, Andreas Seidelin.

Johansen, Steen (1948-1954), Bibliografi over NF.S. Grundtvigs Skrifter, I-IV, København, Gyldendal. 


\section{Grundtvigs vej til Saxo}

Jørgensen, Ellen (1931), Historieforskning og Historieskrivning i Danmark indtil Aar 1800, I, København, Den danske historiske Forening og Carlsbergfondet.

- (1943), Historiens Studium i Danmark i det 19. Aarhundrede, København, Den danske historiske Forening og Carlsbergfondet.

Jørgensen, Jon Gunnar, Friis-Jensen, Karsten og Mundal, Else (red.) (2010), Saxo \& Snorre, København, Museum Tusculanums Forlag.

Kingo, Thomas (1939-1974), Samlede Skrifter, ved Brix, Hans, Billeskov Jansen, F.J., Diderichsen, Paul m.fl. (udg.), I-VII, København, Ejnar Munksgaard.

Krantz, Albert (1546), Chronica regnorum Aquilonarium, Danie, Suetie, Norvagice, Straßburg, Johann Schottus.

Lundgreen-Nielsen, Flemming (1968), Den nordiske fortalling $i$ det 18. århundrede, København, G.E.C. Gads Forlag (Studier fra Sprog- og Oldtidsforskning 268).

- (1980), Det handlende ord. N.F. S. Grundtvigs digtning, litteraturkritik og poetik 1798-1819, 1-2, København, G.E.C. Gad.

- (1982), "Grundtvig og Det litterære Selskab 1805-1822” i Grundtvig-Studier 1982, 62-73.

- (1992), "Grundtvig og danskhed” i Feldbæk, Ole (red.), Dansk Identitetshistorie, 3. Folkets Danmark 1848-1940, København, C.A. Reitzels Forlag, 9-187.

- (2008), "Nordens pronominale guld. Portræt af et Grundtvig-digt" i Collin, Finn og Riis Flor, Jan (red.), Filosofiske studier Bind 24. Festskrift tilegnet Docent, dr. phil. Carl Henrik Koch, København, Institut for Medier, erkendelse og formidling, 237-250.

Mallet, [Paul-Henri] (1755), Introduction à l'histoire de Dannemarc, ou l'on traite de la Réligion, des Loix, des Mours \& des Usages des Anciens Danois, København.

Meursius, Johannes (1630), Historia Danica libri III, København, Joach. Moltke.

- (1631), Elnothus, monachus Cantuariensis. De vita \& passione, S. Canuti, regis Dania, ved Meursius, Johannes (udg.), København, Joach. Moltke.

Müller, Peter Erasmus (1823), Critisk Undersøgelse af Danmarks og Norges Sagnhistorie eller om Trovardigheden af Saxos og Snorros Kilder, København, Den Gyldendalske Boghandling.

Rafn, C.C., se Fundinn Noregr.

Registrant over N.F.S. Grundtvigs papirer (1957-1964), I-XXX, København, Grundtvig-Selskabet af 8. September 1947 og Det danske Sprog- og Litteraturselskab. Forkortet: Reg

[Resen, Peder Hansen], se Snorre. 


\section{Flemming Lundgreen-Nielsen}

Rønning, F. (1904), Den Grundtvigske slegt. Bidrag til dens historie, København, Karl Schønbergs Forlag.

[Saxo Grammaticus] Den Danske Krønicke (1575), ved Vedel, Anders Sørensen (overs.), København, Baltzer Kaus. 2. udgave (1610).

[Saxo Grammaticus] Danica Historia Libris XVI, ved Lonicer, Philip (udg.), Frankfurt am Main, And. Wechelus.

Saxonis Grammatici Historic Danice Libri XVI (1644), ved Stephanius, Stephanus Johannis (udg.), København, Joachim Moltke.

Schøning, Gerhard (1771, 1773, 1781), Norges Riiges Historie, 1-2 Sorø, Heineck Mumme og Faber, 3 København, Gyldendal.

Skovgaard-Petersen, Karen (2002), Historiography at the Court of Christian IV (1588-1648). Studies in the Latin histories of Denmark by Johannes Pontanus and Johannes Meursius, København, Museum Tusculanums Forlag.

Snorre Sturlesøn (1633), Norske Kongers Chronica, ved Friis, Peder Claussøn (overs.) og Worm, Ole (udg.), København, Joachim Moltke.

Snorre Sturlesen (1757), Norske Kongers Krønike, nu paa nye oplagt og formeret med Tillag af adskillige Steder, ved Friis, Peder Claussøn (overs.) og unævnt udgiver, if. udateret "Fortale til den Gunstige Læser" identisk med forlæggeren (Andreas Hartvig Godiche), København, A.H. Godiche.

Snorro Sturlæ (1645), Edda Islandorum, ved Resen, Peder Hansen (udg.), København, Henrik Gødianus.

Steenstrup, Johannes (1889), Historieskrivningen i Danmark i det 19de Aarhundrede (1801-1863), København, Den danske historiske Forening.

Stephanius, Stephanus Johannis (1645), Note Uberiores in Historiam Danicam Saxonis Grammatici. Una cum Prolegominis ad easdem Notas, Sorø, Henricus Crusius.

Suhm, Peter Friedrich (1771), Om Odin og den Hedniske Gudelere og Gudstieneste udi Norden, København, Brødrene Berling.

Syv, Peder (1688), Aldmindelige Danske Ord-Sproge og korte Lardommes Første og anden Deel, København, Christian Geertzen.

Toldberg, Helge (1946), Grundtvig som filolog, København, G.E.C. Gads Forlag.

Vinilandicus, Peter Andersen (2012), Nordens gotiske storhedstid, Odense, Syddansk Universitetsforlag.

[Worm, Ole] Olai Wormii et ad eum doctorum virorum epistole (1751), II, København. 